NBER WORKING PAPER SERIES

\title{
FROM ANTI-VAX INTENTIONS TO VACCINATION: \\ PANEL AND EXPERIMENTAL EVIDENCE FROM NINE COUNTRIES
}

\author{
Vincenzo Galasso \\ Vincent Pons \\ Paola Profeta \\ Michael Becher \\ Sylvain Brouard \\ Martial Foucault \\ Working Paper 29741 \\ http://www.nber.org/papers/w29741
}

\author{
NATIONAL BUREAU OF ECONOMIC RESEARCH \\ 1050 Massachusetts Avenue \\ Cambridge, MA 02138 \\ February 2022
}

Survey Data from the project Attitudes on COVID-19: A Comparative Study, chaired by Sylvain Brouard and Martial Foucault (Sciences Po); the December 2020 and the June/July 2021 waves of the survey received ethics approval from IE University (IERC-12/2020-2021 and IERC-30/2020-2021). Financial Support from ANR (French Agency for Research) - REPEAT grant (Special COVID-19), Unicredit Foundation and French region Nouvelle Aquitaine are gratefully acknowledged. The views expressed herein are those of the authors and do not necessarily reflect the views of the National Bureau of Economic Research.

At least one co-author has disclosed additional relationships of potential relevance for this research. Further information is available online at http://www.nber.org/papers/w29741.ack

NBER working papers are circulated for discussion and comment purposes. They have not been peer-reviewed or been subject to the review by the NBER Board of Directors that accompanies official NBER publications.

(C) 2022 by Vincenzo Galasso, Vincent Pons, Paola Profeta, Michael Becher, Sylvain Brouard, and Martial Foucault. All rights reserved. Short sections of text, not to exceed two paragraphs, may be quoted without explicit permission provided that full credit, including () notice, is given to the source. 
From Anti-vax Intentions to Vaccination: Panel and Experimental Evidence from Nine Countries Vincenzo Galasso, Vincent Pons, Paola Profeta, Michael Becher, Sylvain Brouard, and Martial Foucault

NBER Working Paper No. 29741

February 2022

JEL No. D83,I12,I18

\begin{abstract}
Millions of people refuse COVID-19 vaccination. Using original data from two surveys in nine OECD countries, we analyze the determinants of anti-vax intentions in December 2020 and show that half of the anti-vax individuals were vaccinated by summer 2021. Vaccinations were more likely among individuals aged 50+, exposed to COVID-19, compliant with public restrictions, more informed on traditional media, trusting scientists, and less concerned about vaccines' side effects. We run a survey experiment with informational messages. In EU countries, a message about protecting health largely increases vaccinations, even among anti-vax individuals. In the U.K. and U.S., a message about protecting the economy generates similar effects. Our findings suggest that informational campaigns should adopt adequate narratives and address concerns about vaccines' side effects.

Vincenzo Galasso

Università Bocconi-IGIER

Milano, Italy

vincenzo.galasso@unibocconi.it

Vincent Pons

Harvard Business School

Morgan Hall 289

Soldiers Field

Boston, MA 02163

and NBER

vpons@hbs.edu

Paola Profeta

Università Bocconi

via Roentgen 1

20136 Milano

Italy

paola.profeta@unibocconi.it

Michael Becher

IE University

Paseo de la Castellana, 259

Madrid 28046

Spain

and Institute for Advanced Study in Toulouse

michael.becher@ie.edu

Sylvain Brouard

CEVIPOF (Centre de recherches politiques)

98, rue de l'Université

Paris 75007

France

sylvain.brouard@sciencespo.fr

Martial Foucault

CEVIPOF (Centre de recherches politiques)

98 rue de l'Université

Paris 75007

France

martial.foucault@sciencespo.fr
\end{abstract}


Despite large take-up rates in most OECD countries, millions of people still refuse COVID-19 vaccination. The large number of unvaccinated individuals raises major concerns about the diffusion of the virus (1). Moreover, anti-vax individuals are often very vocal about their choice and many use social media to convince undecided individuals not to get vaccinated $(2,3)$. Hesitancy about COVID-19 vaccines was to be expected, given preexisting opposition to other vaccines (4-7). Yet, a year since their initial introduction and in spite of more than four billion people around the world being vaccinated, vaccine hesitancy remains an important issue in fighting COVID-19. The pandemic and the lockdown measures put in place in many countries for more than a year have had extraordinarily large health, economic, and psychological costs $(8,9)$. Mass vaccination may represent the only alternative solution to returning to restrictive public health measures. Yet, so far, the availability of free and easy-to-access vaccines and the introduction of COVID-19 certificates often required to work and access public places - have not been sufficient to push vaccination rates above the threshold required to end the pandemic.

Hesitancy or outright refusal of vaccination is typically due to complacency towards the disease and lack of confidence in the vaccine (10-13). A recent literature on COVID-19 vaccination hesitancy has shown refusal to be vaccinated to be higher among younger cohorts, women, and low educated individuals, among some minorities and religious groups, and among individuals with low trust in government, low perceived threat of getting infected, and large concerns with vaccine safety and effectiveness (14-19). Addressing the concerns of individuals with low vaccination intentions is crucial to improve vaccination rates. Public policies that increase the cost of not being vaccinated, such as requiring a COVID-19 vaccination certificate to work or to access public places may bring some hesitant individuals to get vaccinated (20), but they have also proved very controversial. Public health messages often increase vaccination intentions, but not necessarily actual vaccinations, and financial incentives do not seem effective (21-23).

We use original data from two waves of a nationally representative survey of the adult population conducted in nine OECD countries to investigate the determinants of vaccination intentions in December 2020, and of actual vaccination behavior in the following six months.

In December 2020, vaccines had already been developed and authorized for the large public, but massive vaccination campaigns had not yet started. We analyze the role of socio-demographic characteristics as well as COVID-related health perceptions, attitudes, and concerns in explaining vaccination intentions - prior to the vaccination campaigns. We also identify the main characteristics and attitudes of individuals with anti-vax intentions.

Using the June/July 2021 survey data, we then analyze these individuals' actual vaccination behavior, given their prior vaccination intentions. From December 2020 to summer 2021, several important events occurred. Vaccination campaigns reached (almost) all citizens in the countries we study. Additional information about COVID-19 and its vaccines became available. Moreover, individuals continued to have their personal experiences related to the coronavirus, and also to the vaccines. We study the determinants of actual vaccination decisions, given the initial intentions, and isolate the main characteristics leading individuals with anti-vax preferences to undergo vaccination.

Finally, we evaluate the effectiveness of different information treatments, provided with the December 2020 survey, to increase immediate individuals' vaccination intentions (in December 2020), and, more importantly, to modify their actual vaccination behavior, as reported in the June/July 2021 survey. These findings are of crucial importance to understand which message to use in information campaigns targeting anti-vax individuals. 


\section{Survey Data}

Our data (24) exploit the panel component of two survey waves conducted in December 2020 and in June/July 2021, respectively, in nine countries: Australia, Austria, France, Germany, Italy, New Zealand, Sweden, the United Kingdom (U.K.) and the United States (U.S.). Our sample includes a total of 6,379 respondents who were successfully surveyed in both waves, corresponding to $59 \%$ of the participants in the December 2020 wave.

All the countries included in the survey have high income per capita and advanced health systems, allowing us to pool their data in a common analysis. However, the pandemic affected them very differently. By the end of 2020, Italy and the U.K. were among the countries with the highest mortality rate in the world (16), while few countries had a lower mortality rate than New Zealand and Australia. Each country implemented specific lockdown measures. The informational messages and the timing of the vaccination campaigns also differed. Most EU countries launched their campaigns at the end of December 2020, but New Zealand and Australia did not do so until February 2021 (see Table S1 in the Supplementary Material). These cross-country differences increase the external validity of our findings.

The first wave of the survey was administered between December $2^{\text {nd }}$ and December $10^{\text {th }} 2020$ (see Table S2 in the Supplementary Material), when most countries were experiencing the second wave of the pandemic, and new lockdown measures targeted for the holiday season, were imposed.

Vaccines had just been authorized. News about their upcoming deployment were in the media, but there was still little discussion (and perhaps concern) about possible side effects. The second wave of the survey was administered between June $28^{\text {th }}$ and July $13^{\text {th }}$ 2021. At the end of June 2021, the percentage of people in the total population who had received at least one shot of a COVID-19 vaccine varied between $14.1 \%$ in New Zealand and $65.8 \%$ in the U.K., largely reflecting the timing and organization of the vaccination campaigns in the different countries. Most countries prioritized health care workers and elderly people and only managed to make a vaccine available to the entire adult population, including the young adults, in early summer 2021.

Both waves of the survey recorded individuals' attitudes and behavior towards COVID-19 and COVID-19 vaccination. The surveys also collected information on individuals' socio-demographic characteristics such as age (four age groups: 18-34, 35-49, 50-59, and 60+), gender, type of occupation (white collar, blue collar, service workers, and inactive), level of education (no high school, high school, and college), living arrangements (living with family, living alone and living with friends), political orientation (liberal, centrist, and conservative, corresponding respectively to $0-3,4-6$, and 7-10 on the $0-10$ scale of political ideology from left to right), and level of information. We capture consumption of traditional media by averaging the responses to questions on how frequently the individual (a) watches TV; (b) listens to the radio; and (c) reads the newspaper, with possible answers being never (corresponding to category 1), 1 or 2 days a week (2), 3 or 4 days a week (3), 5 or 6 days a week (4), or every day (5). We also use information on how much individuals use social media, on the same 1-5 scale.

The surveys collected information on respondents' experiences, expectations, and behavior on COVID-related issues. Individuals reported whether they - or their relatives or friends - had been infected with COVID-19. They were asked how likely they think they are to be infected if they return to their normal life (on a 0-10 scale) and how likely they think they are to be seriously ill if infected with COVID-19 (on a 0-10 scale). Moreover, individuals reported their level of risk aversion, by answering how difficult it is for them to accept health risks (on a $0-10$ scale). The December 2020 wave also collected information about individuals' compliance with several COVID-19 related health and social distancing rules, which were in place (or about to be reintroduced) in most countries in our sample, such as coughing into one's elbow, stopping hugging or greeting, avoiding crowded places, and wearing face masks. 
To measure confidence towards COVID-19 vaccines, questions were asked on trust in scientists, on elements of conspiracy theories, and on the COVID-19 vaccine trial procedure. In both waves, respondents were asked how much they trust scientists (on a 1-4 scale, from "not at all" to "completely") and how much they believe the following two statements to be true, on a 1-10 scale (from completely unlikely to very likely): (i) "The virus has been created by large corporations because some of them can directly profit from it" and (ii) "The virus was created by China to increase its power in the world.” In the second wave, on a 1-10 scale (from completely unlikely to very likely), respondents were asked whether they believe that, due to the expedition of clinical trials, the possible negative consequences of COVID-19 vaccines were not fully analyzed.

Both waves gathered information on individuals' attitudes towards COVID-19 vaccination namely, whether a vaccine is the solution to the pandemic and whether vaccination should be made mandatory. The first wave (in December 2020) elicited individuals' willingness to be vaccinated in the next few months on a 0 to 10 scale (from not at all likely to extremely likely). The second wave (in June/July 2021) obtained information about the individuals' actual vaccination behavior and, for those who had not yet been vaccinated, about their willingness to get vaccinated in the near future. Summary statistics for all the variables used in this study, normalized on a 0-1 range for the regression analysis, are shown in Table S3 in the Supplementary Material.

\section{Vaccination Intentions}

Figure 1 shows the distribution of vaccination intentions in the nine countries in our sample. In each country, a wide dispersion emerges, with many individuals concentrated on extreme positions: 0 (not at all likely to be vaccinated) and 10 (extremely likely). However, large differences also exist across countries. Let us define as anti-vax individuals with an answer between 0 and 3, with hard anti-vax being the individuals who answered 0 , and soft anti-vax those with an answer between 1 and 3. Moreover, let us define as pro-vax individuals with an answer between 7 and 10, and as undecided those with an answer between 4 and 6. In December 2020, the share of individuals with anti-vax intentions ranged from $10 \%$ in the U.K. to $37 \%$ in Austria, and the proportion of pro-vax went from 38\% in France to $74 \%$ in the U.K.

The existing literature on vaccine hesitancy suggests that three main factors hinder vaccination $(10,11)$ : complacency towards the disease, lack of confidence in the vaccine, and vaccination inconvenience. Complacency implies that individuals perceive the probability of getting infected and the risk of the disease to be low, so that vaccination is not deemed necessary (17). Confidence requires trust in the effectiveness and safety of the vaccine, in the health services delivering it, and in the motivations of the policy-makers launching the vaccination campaign (18). Inconvenience relates to physical availability, affordability, and appeal of the immunization service.

Figure 2 (left panel) and Table S4 in the Supplementary Material report the estimated coefficients of a large set of explanatory variables used in a linear regression model with vaccination intentions as the outcome variable (see Methods in the Supplementary Material). Our findings suggest that socio-demographic characteristics affect vaccination intentions: adults (35-49) are less willing to be vaccinated than young individuals (18-34), service workers and blue collar workers less than white collar workers, and women less than men. Behavioral factors related to complacency matter too. Vaccination intentions are lower among individuals who are less informed through traditional media, among people who comply less with public health rules, among people who believe that they are less likely to be infected and less likely to be severely ill, and among individuals of undeclared political ideology. Individual attitudes, mostly related to trust, are also crucial. Vaccination intentions are lower among people who have low trust in scientists, who believe that there was not enough time to assess vaccines' side effects, and that COVID-19 was created by large corporations to profit from it. Columns 2 to 4 in Table S4 report the results respectively for three 
sets of countries: EU countries (Austria, France, Germany, Italy and Sweden), the U.K. and U.S., and Australia and New Zealand. Most of these findings hold in each of the three geographical samples.

Our data allow to provide an ideal type of the individuals with anti-vax intentions, i.e., those who answered $0-3$ on the $0-10$ scale for vaccination intentions. We also distinguish between hard antivax (who answered 0) and soft anti-vax (who answered 1-3). Figure 2 (right panel) and Table S5 in the Supplementary Material show the estimated coefficients of a similar regression, but with antivax intentions as the outcome variable. People with anti-vax intentions are more likely to be older than 35 and to be women, they are less informed (through traditional media), less compliant with public health rules, they feel less at risk of being infected and of becoming seriously ill, but they are more risk averse. They are also less likely to trust scientists and more likely to believe that vaccines' side effects have not been sufficiently studied. Most of these findings hold both for hard and soft anti-vax (Table S5, columns 2 and 3), as well as for anti-vax in our three subsets of countries - EU countries, the U.K. and U.S., and Australia and New Zealand (Table S5, columns 46). However, the percentage of individuals with anti-vax intentions is significantly larger in EU countries: $(\mathrm{M}=0.255$ vs. 0.143 , Mdiff $=0.112,95 \%$ CI $[0.091 ; 0.133])$.

Unsurprisingly, given the high level of vaccine hesitancy, mandatory vaccination has been largely advocated in the public debate, but also fiercely opposed. We use a question in December 2020 to evaluate the support for compulsory vaccination, when the debate was less heated and polarized. Respondents were asked if they agree that being vaccinated should be compulsory, since public health reasons are more important than the respect for individual freedom of choice, or, on the opposite, that being vaccinated should not be compulsory, as the respect for individual freedom of choice is more important. The share of individuals in favor of compulsory vaccination varies widely across countries, from $24 \%$ in Austria to $62 \%$ in Australia. Overall, the percentage of individuals favoring mandatory vaccination is significantly smaller in EU countries: $(\mathrm{M}=0.346$ vs. 0.536 , Mdiff $=-0.190,95 \%$ CI [-0.209; -0.172]). These cross-country differences in opposition to mandatory vaccination are in line with cross-country differences in anti-vax intentions.

\section{Vaccination Behavior}

Do individuals follow up on their early vaccination intentions? Figure 3 plots the vaccination rate (elicited in the second wave, in June/July 2021) by vaccination intentions (reported in the first wave, in December 2020) for the whole sample and then separately for EU countries, for the U.K. and U.S., and for Australia and New Zealand. Clearly, vaccination intentions are crucial to explain actual vaccination behavior. Among the hard anti-vax individuals who answered 0 (not at all likely to be vaccinated) in December 2020, the vaccination rate is $32.6 \%$, while among the hard pro-vax, who answered 10 (extremely likely), the vaccination rate is $83.6 \%$.

We now investigate which individual factors are important in modifying - or confirming - early vaccination intentions. Vaccination campaigns began shortly after our first survey wave that recorded vaccination intentions in December 2020. Vaccines became available in all nine countries in our sample (see Table S1) and a heated debate about their safety emerged. These elements varied across countries, since different vaccination and information campaigns took place, as well as across individuals, who had different personal experiences and were exposed to different types of information. In our empirical analysis, we use data from the December 2020 survey wave to study whether initial individual characteristics, possibly interacting with the events, which took place after December 2020, correlate with the actual vaccination behavior, given the initial vaccination intentions.

Figure 4 (left panel) and Table S6 (column 1) in the Supplementary Material report the estimated coefficients of a large set of explanatory variables, including vaccination intentions, used in a linear 
regression model with actual vaccination as the outcome variable (see Methods in the Supplementary Material). Our findings confirm the strong explanatory power of the December 2020 intentions on the actual vaccination behavior, but they also unveil additional important determinants. Controlling for vaccination intentions, older cohorts are more likely to have received the vaccination - perhaps because young individuals were offered this opportunity only later on (see Table S1 in the Supplementary Material), while blue collar workers and inactive people are less likely to have been vaccinated than white collar workers. Behavioral and attitudinal aspects matter too. Concerns about serious health risks, indirect exposure to COVID-19 through friends and relatives, as well as living with one's family and compliance with public health rules, all have positive signs - thereby suggesting that low complacency with COVID-19 helps vaccination. Information and trust are also important elements of persuasion. Individuals with more exposure to news on TV, radio, and newspapers (but not on social media) and more trustful of scientists were more likely to get their jabs. One of the most crucial determinants is confidence in the vaccines. The belief that expedited trials did not allow careful studies of the possible side effects of vaccinations largely reduces actual vaccination behavior. Table S6 shows that most of these factors are significantly correlated with vaccination in all three geographical subsamples, yet interesting differences emerge. Living with one's family and traditional media consumption matter mostly in EU countries, whereas trust in scientists is crucial in Anglo-Saxon countries. Blaming COVID-19 on large corporations is a crucial impeding factor in EU countries. Conservatives are more likely to get vaccinated in Australia and New Zealand, but less in the U.K. and the U.S.

Are some of these factors able to motivate even individuals with previous anti-vax intentions (as elicited in December 2020) to get their jabs? Figure 4 (right panel) and Table S7 (column 1) in the Supplementary Material report the estimated coefficients of the same factors on the same outcome, actual vaccination, but after restricting the sample to individuals with anti-vax intentions (who answered 0-3 to the question on vaccination intentions in the December 2020 wave). We find that older age, concerns with health risks, and indirect exposure to COVID-19 through friends or relatives increase vaccination among individuals with anti-vax intentions. Individuals compliant with public health rules are also more likely to get vaccinated, despite their initial anti-vax intentions, perhaps due to the mounting social pressure to be vaccinated. Information and trust seem equally crucial to convince anti-vax people. Individuals with high consumption of traditional media and more trust in scientists are more likely to get vaccinated, regardless of their initial level of vaccination hesitancy. Instead, concerns about negative health consequences from vaccination are an important factor decreasing the likelihood of vaccination among anti-vax individuals.

Interestingly, risk aversion reduces actual vaccination among anti-vax, thereby suggesting that these individuals may be more concerned about possible negative side effects of vaccination than about the risk of getting COVID-19. A similar picture emerges when considering our three geographical subsamples separately (see Table S7, columns 2-4).

\section{Experimental Evidence}

Our panel data evidence suggests that more informed individuals are more likely to get vaccinated even if, early on, they had little (or no) intention to do so. Instead, being complacent about COVID19 or having low confidence in vaccines or low trust in scientists hinder vaccination. These descriptive findings suggest a possible role for information messages in convincing people with anti-vax intentions to get vaccinated. The use of a large set of controls in our regression analysis reduces concerns about omitted variable bias, but it may not fully eliminate it. In order to obtain causal evidence on the impact of information on vaccination behavior, we exploit a survey experiment.

In our December 2020 survey, respondents in each country were randomly assigned to four treatment groups or a control group. Individuals in all treatment groups were exposed to the 
following message: "The only way to become immune to COVID-19 in the long run is by vaccination.” Then, depending on the treatment group, they also saw one of the following four messages: (i) "In this case, if you were vaccinated, you could avoid getting infected with the virus" (henceforth, the Self-protection group); (ii) "In this case, if you were vaccinated, you might be able to avoid passing the virus on to others" (Protecting Others); (iii) "In this case, if a person was vaccinated, they could avoid getting infected with the virus. This would protect the health of people in your country [in each country, respondents saw the actual name of the country]" (Protecting Health); or (iv) "In this case, if a person was vaccinated, they could avoid getting infected with the virus. It would allow a return to normal economic activity and reduce unemployment” (Protecting the Economy). Individuals in the control group received no informational content. Respondents in all groups were then asked "If a vaccine against COVID-19 was available in the next few months, would you agree to be vaccinated?”, with possible answers ranging from 0 (not at all likely) to 10 (extremely likely). In the June/July 2021 survey, the same individuals were asked whether they had received at least one shot of a COVID-19 vaccine. Table S8 in the Supplementary Material reports the balance tests for the personal characteristics of the survey participants across the four experimental treatments and the control group. All predetermined variables are well-balanced: out of 104 coefficients, four are significant at the 5\% level and eight others at the $10 \%$ level, which is in line with what would be expected. Analogously, the attrition rate from the first to the second wave is not significantly different across treatments (see Table S8, column 26).

Figure 5 (and Table S9, columns 1-5, in the Supplementary Material) shows the results of our empirical analysis, in which we regress our two main outcome variables - vaccination intentions and actual vaccination behavior - on the four treatment dummies, controlling for country fixed effects. The altruistic messages about Protecting Others, Protecting Health, and Protecting the Economy all have a positive and significant impact on individual intentions elicited immediately after the treatments, in the same December 2020 survey (Figure 5, upper left panel, and Table S9, column 1). These impacts are sizable: 2.2 percentage points (significant at the $10 \%$ level), 3.0 percentage points (significant at the $5 \%$ level), and 3.8 percentage points (significant at the $1 \%$ level) respectively, which correspond to $3.5 \%, 4.8 \%$, and $6.1 \%$ of the mean in the control group. Interestingly, the effect of the Self-protection message, while positive, is lower than these three effects, and it is the only one that is not statistically significant. A possible concern with responses on vaccination intentions, which are obtained immediately after the treatments, is social desirability bias. Individuals may over-report their vaccination intentions in order to comply with social norms after receiving treatments that highlighted the importance of getting vaccinated.

We now turn to the effects on vaccination, as reported six months later, in the June/July 2021 wave. In this case, the social desirability bias is less likely to occur, both because the informational treatments were received six months earlier and because individuals are asked to report their actual behavior, rather than their intentions. Hence, misreporting about actual vaccination amounts to telling a clear lie. Strikingly, the persuasive effects of the altruistic messages persisted in the following months, translating in a higher probability of the recipients actually getting vaccinated (see Figure 5, upper right panel and Table S9, column 2). The effects on vaccination rates are of similar magnitudes as the effects on vaccination intentions: 2.6 percentage points for Protecting Others (significant at the 10\% level), 3.8 percentage points for Protecting Health (significant at the 5\% level), and 2.9 percentage points for Protecting the Economy (significant at the $10 \%$ level), which account for $3.9 \%, 5.7 \%$, and $4.3 \%$ of the mean in the control group. By contrast, the effect of Self-protection is once again small and not significant. Results displayed in the lower panels of Figure 5 (and in Table S9, columns 3-5) show that the altruistic messages have differential effects across countries. The message about Protecting Health is most effective in the EU countries (Austria, France, Germany, Italy and Sweden), whereas the messages about Protecting Others and particularly about Protecting the Economy are more impactful in the U.K. and U.S. Finally, we do not measure any significant effect in Australia and New Zealand. 
Besides their effectiveness in increasing the average vaccination rate, do these messages also help reducing anti-vax intentions and convincing individuals expressing such intentions to get vaccinated? Figure 6, upper left panel, and Table S9, column 6, show the effect of our treatments on expressing anti-vax intentions in the December 2020 survey, that is, on answering 0-3 (on a 0-10 scale) to the question asking respondents whether they agree to be vaccinated. Being exposed to one of the altruistic messages (Protecting Others, Protecting Health, or Protecting the Economy) reduces the probability of the respondent reporting anti-vax intentions by 3.0 to 5.0 percentage points (12.6\% to $20.9 \%$ of the mean in the control group).

The other panels in Figure 6, as well as columns 7-10 in Table S9, show the results of our treatments on the actual vaccination behavior of the subsample of individuals who had reported anti-vax intentions in the first survey. It is important to note that this group of individuals may be endogenously selected. Indeed, as just discussed (and as reported in the upper left panel of Figure 6), the number of anti-vax individuals is lower in the treatment groups. If anything, we should expect the subset of people reporting anti-vax intentions despite receiving treatments promoting vaccination to have a lower predisposition to get vaccinated than anti-vax individuals in the control group. Therefore, concerns that the subsample of anti-vax individuals may be endogenous should work against us finding a positive treatment effect on their vaccination rate.

Pooling data from all countries, we do not find evidence that, on average, the treatments induce people who stated anti-vax intentions in the December 2020 survey to get vaccinated (see Figure 6, upper right panel, and Table S9, column 7). Due to the endogenous sample concerns, this point estimate is likely to represent a lower bound on the true effect. However, this average effect conceals important differences across countries. In fact, consistently with the previous results on vaccination rates, we find that Protecting Health is effective in the EU countries (see Figure 6, lower left panel, and Table S9, column 8). In line with the previous results, the coefficient for the message about Protecting the Economy is positive in the U.K. and U.S., yet not statistically significant (see Figure 6, lower right panel, and Table S9, column 9) - possibly due to the limited number of observations. The magnitude of the informational effects is sizable, even though, once again, our point estimates are lower bounds on the true effects. In the EU countries, the Protecting Health message increases the vaccination rate among individuals with anti-vax intentions by 8.3 percentage points (16.6\% of the mean in the control group) (see Table S9, column 8). In Australia and New Zealand, where mortality rates were lower and vaccination campaigns began later (see Table S1), the vaccination rate of anti-vax is only $10 \%$ (as compared with $51 \%$ in EU countries and $42 \%$ in the U.K. and U.S.) and we do not observe any positive effect of the treatments. Rather, the Self-protection and Protecting Health messages seem to backfire among anti-vax individuals in these two countries (see Table S9, column 10).

\section{Discussion}

Our exploration on longitudinal data of the determinants of intended and effective vaccination, and the experimental analysis on the impact of informational treatments highlight the crucial role of information for the success of Covid-19 vaccination campaigns.

The consumption of traditional media was one of the strongest correlates of intending to get vaccinated in December 2020, overall as well as in each subset of countries: EU countries, the U.S. and U.K., and Australia and New Zealand. By the second wave of our survey, in summer 2021, people who consume more traditional media were more likely to have gotten vaccinated, even controlling for initial vaccination intentions. Vaccination rates were also higher among people who think they are more likely to get Covid or to get seriously ill, and lower among those who believe that the virus was created by large corporations or that the possible negative consequences of 
COVID-19 vaccines were not fully analyzed. Naturally, these beliefs directly reflect the type of information people have about the pandemic.

Our most striking result is that informational treatments provided in the first wave affected not only vaccination intentions expressed in the same survey but also actual vaccination rates recorded six months later. Our messages even increased vaccination among individuals who had initially expressed anti-vax attitudes. Overall, altruistic messages had the largest effect. The important differences in the relative effectiveness of our different treatments across countries indicate that future information campaigns should be tailored to the context to be most impactful. 


\section{References and Notes:}

1. Omer, Saad B., et al. "Promoting COVID-19 vaccine acceptance: recommendations from the Lancet Commission on Vaccine Refusal, Acceptance, and Demand in the USA." The Lancet (2021).

2. Johnson, N.F., Velásquez, N., Restrepo, N.J. et al. The online competition between pro- and anti-vaccination views. Nature 582, 230-233 (2020).

3. Ball, P. (2020). Anti-vaccine movement could undermine efforts to end coronavirus pandemic, researchers warn. Nature, 581(7808), 251.

4. H. J. Larson \&.... Addressing the vaccine confidence gap. The Lancet 378, 526-535 (2011).

5. Megget, K. (2020). Even covid-19 can’t kill the anti-vaccination movement. BMJ, 369.

6. Schaffer DeRoo S, Pudalov NJ, Fu LY. Planning for a COVID-19 Vaccination Program. JAMA. 2020;323(24):2458-2459.

7. COCONEL Group. (2020). A future vaccination campaign against COVID-19 at risk of vaccine hesitancy and politicisation. The Lancet. Infectious diseases, 20(7), 769.

8. Galasso, V. and M. Foucault (2020), "Working during COVID-19: Cross-country evidence from real-time survey data", OECD Social, Employment and Migration Working Papers, No. 246, OECD Publishing, Paris,

9. $\quad$ S.K. Brooks, R. K. Webster, L. E. Smith, L. Woodland, S. Wessely, N. Greenberg, G.J. Rubin. The psychological impact of quarantine and how to reduce it: rapid review of the evidence. The Lancet. 395, 912-920 (2020).

10. Dubé, E., Gagnon, D., Nickels, E., Jeram, S., \& Schuster, M. (2014). Mapping vaccine hesitancy-Country-specific characteristics of a global phenomenon. Vaccine, 32(49), 6649-6654.;

11. MacDonald, N. E. (2015). Vaccine hesitancy: Definition, scope and determinants. Vaccine, 33(34), 4161-4164.

12. Graham, B. S. Rapid COVID-19 vaccine development. Science 2020; 368(6494), 945-946.

13. Salmon, D. A., Dudley, M. Z., Glanz, J. M., \& Omer, S. B. Vaccine hesitancy: causes, consequences, and a call to action. Vaccine 2015; 33, D66-D71.

14. Lazarus, J. V., Ratzan, S. C., Palayew, A., Gostin, L. O., Larson, H. J., Rabin, K., et al. (2021). A global survey of potential acceptance of a COVID-19 vaccine. Nature Medicine.

15. Razai, M. S., Chaudhry, U. A., Doerholt, K., Bauld, L., \& Majeed, A. (2021). Covid-19 vaccination hesitancy. bmj, 373.

16. Schwarzinger, M., Watson, V., Arwidson, P., Alla, F., \& Luchini, S. COVID-19 vaccine hesitancy in a representative working-age population in France: a survey experiment based on vaccine characteristics. The Lancet Public Health 2021; 6(4), e210-e221

17. Foucault, M., Galasso, V., Pons, V., \& Profeta, P. (2021). COVID-19 Vaccine's Gender Paradox (No. 15996). CEPR Discussion Papers.

18. Khubchandani, J., Sharma, S., Price, J.H. et al. COVID-19 Vaccination Hesitancy in the United States: A Rapid National Assessment. J Community Health 46, 270-277 (2021). https://doi.org/10.1007/s10900-020-00958-xCallaghan et al., 2020,

19. Callaghan T, Moghtaderi A, Lueck JA, et al. Correlates and disparities of intention to vaccinate against COVID-19. Soc Sci Med 2021; 272: 113638. 
20. Gans, J. S. (2021). Vaccine Hesitancy, Passports and the Demand for Vaccination (No. w29075). National Bureau of Economic Research.

21. Milkman, Katherine L., et al. "A megastudy of text-based nudges encouraging patients to get vaccinated at an upcoming doctor's appointment." Proceedings of the National Academy of Sciences 118.20 (2021).

22. Betsch, C., Böhm, R., \& Chapman, G. B. (2015). Using behavioral insights to increase vaccination policy effectiveness. Policy Insights from the Behavioral and Brain Sciences, 2(1), 6173.

23. Chang, T., Jacobson, M., Shah, M., Pramanik, R., \& Shah, S. B. (2021). Financial Incentives and Other Nudges Do Not Increase COVID-19 Vaccinations among the Vaccine Hesitant (No. w29403). National Bureau of Economic Research.

24. S. Brouard, M. Becher, M. Foucault, P. Vasilopoulos. Citizens' attitudes towards COVID-19 - A comparative study. (2020) 
Fig. 1: Distribution of Vaccination Intentions

Distribution of vaccination intentions on a 0 (not at all likely) to 1 (extremely likely) scale, by country.

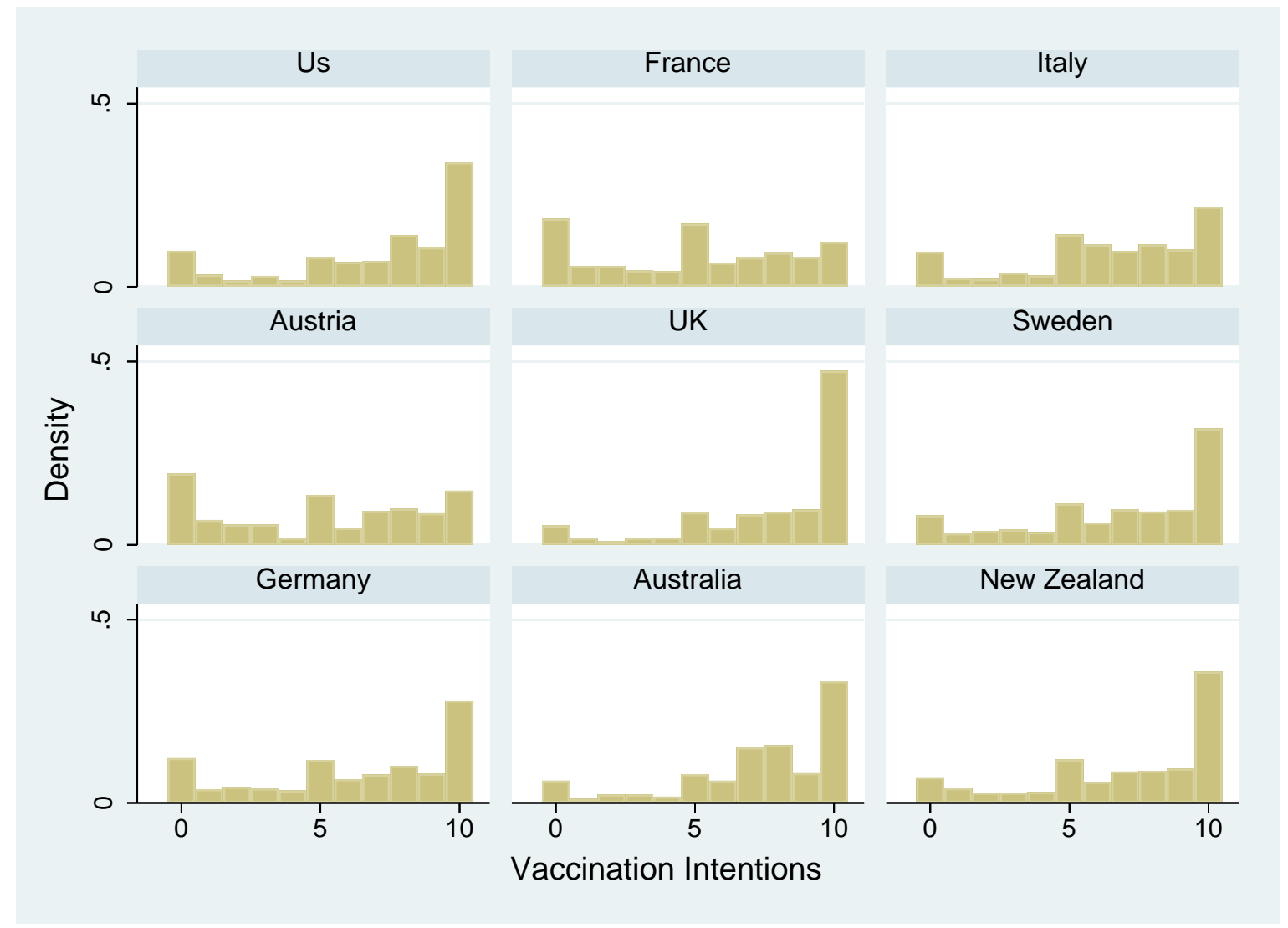


Fig. 2: Determinants of Vaccination Intentions

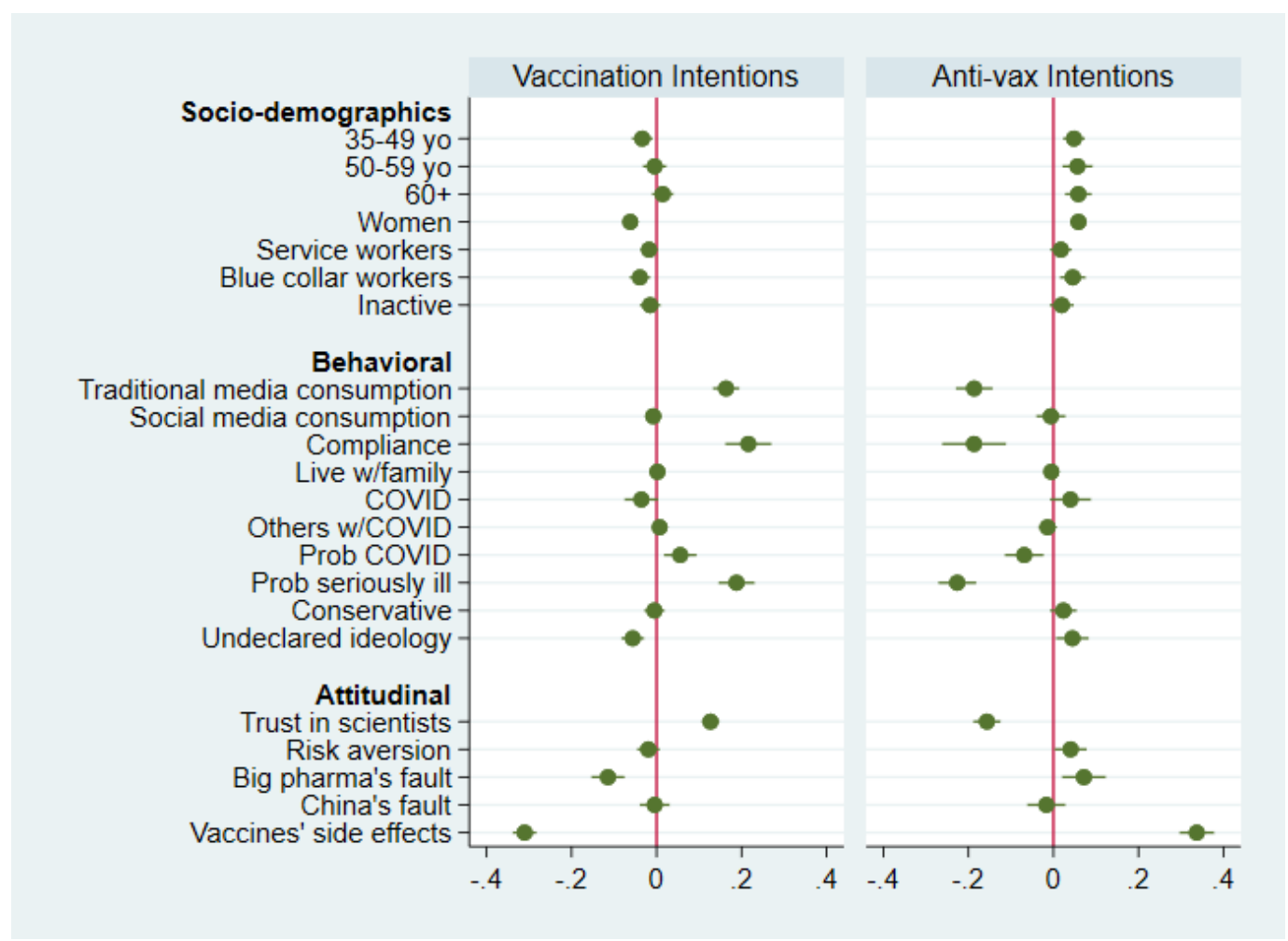

Point estimates of explanatory variables’ coefficients and 95\% confidence intervals, from regressions using pooled data and the outcome variables "Vaccination Intentions" on the left panel and "Anti-vax Intentions" on the right panel (see Table S4 and Methods in the Supplementary Material). 
Fig. 3: Vaccination Rate by Initial Vaccination Intentions

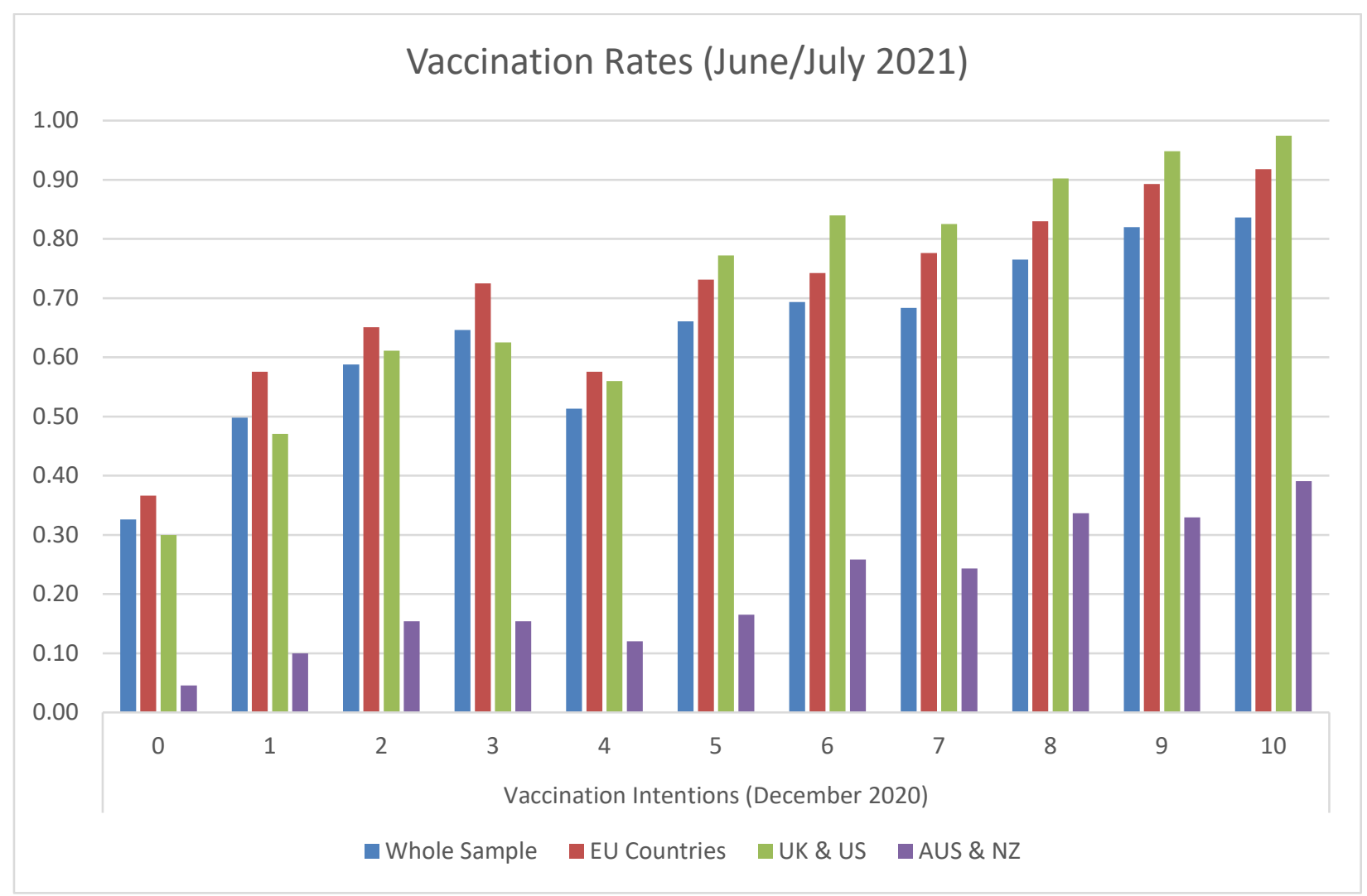


Fig. 4: Determinants of Vaccinations

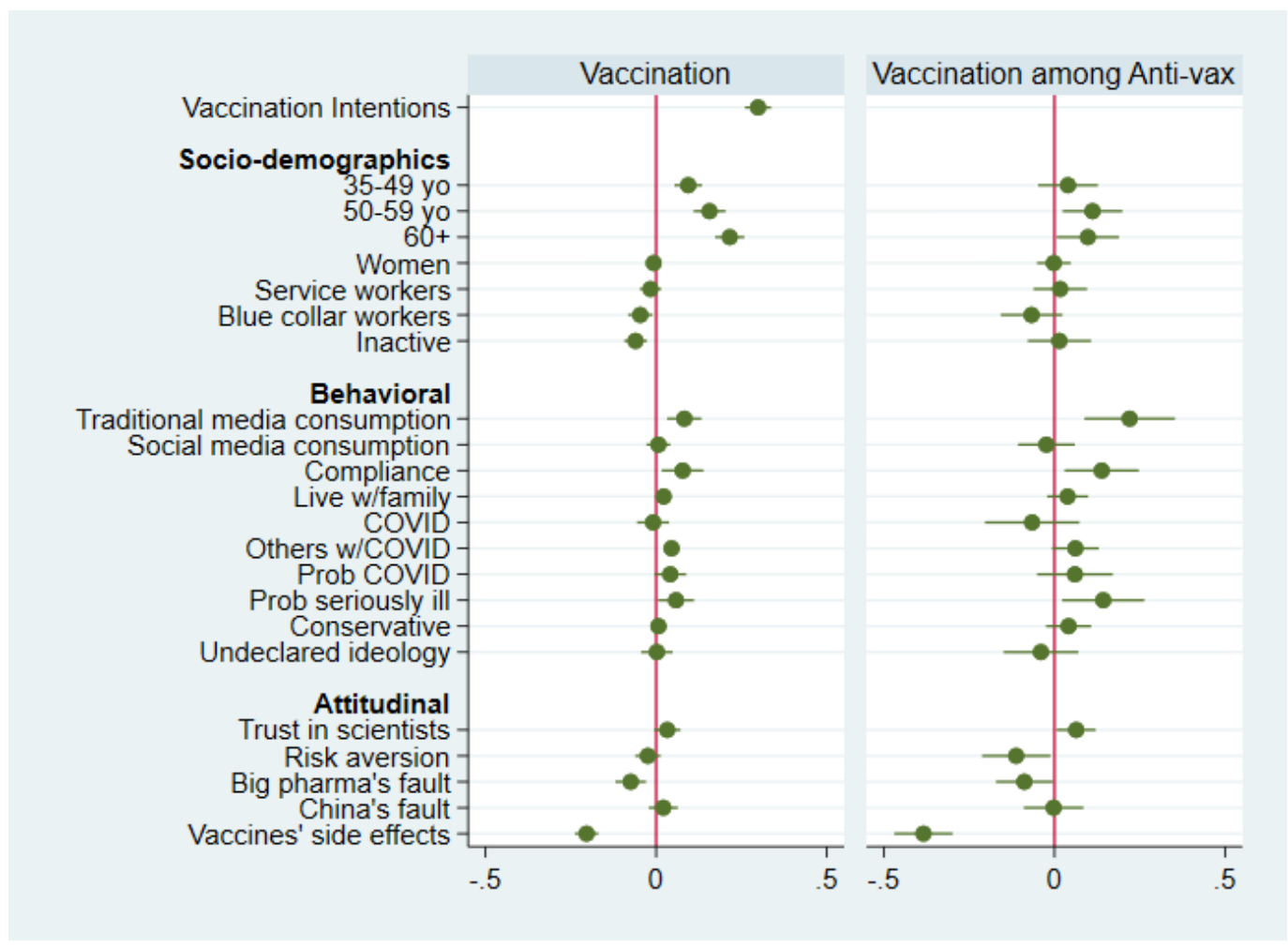

Point estimates of explanatory variables' coefficients and 95\% confidence intervals, from regressions using pooled data and the outcome variable "Vaccination" for the entire sample on the left panel and for the sample of individuals with anti-vax intentions only on the right panel (see Tables S6 and S7 and Methods in the Supplementary Material). 
Fig. 5: Effects of Experimental Treatments

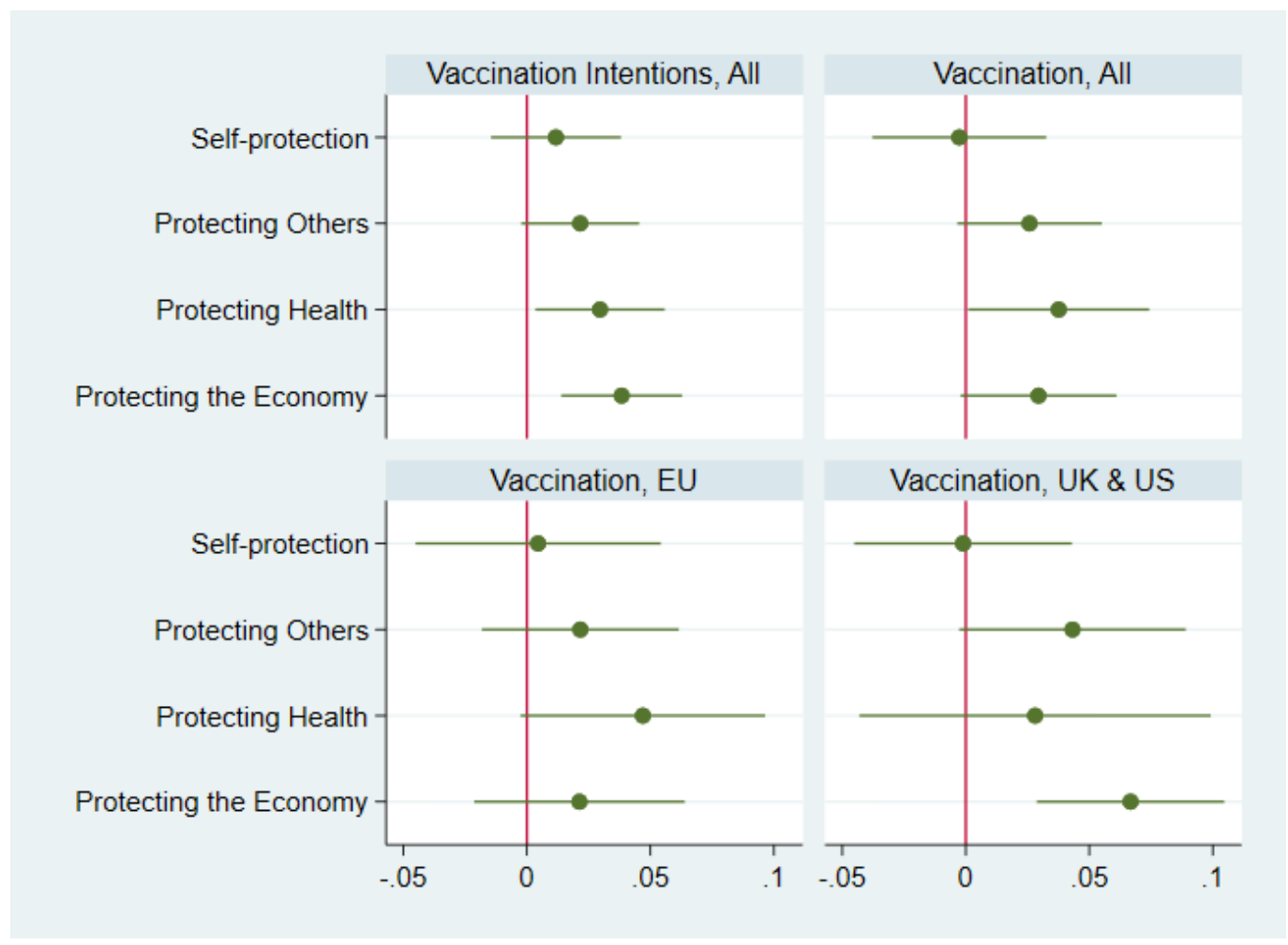

Point estimates and 95\% confidence intervals for each of the four treatments (Self-protection, Protecting Others, Protecting Health, and Protecting the Economy), from regressions using pooled data and the outcome variables "Vaccination Intentions" (upper left panel) and "Vaccination" (upper right panel and lower panels) and also controlling for country fixed effects. In the lower panels, we restrict the sample to EU countries (left) and to the U.K. and U.S. (right). 
Fig. 6: Effects of Experimental Treatments among Anti-vax

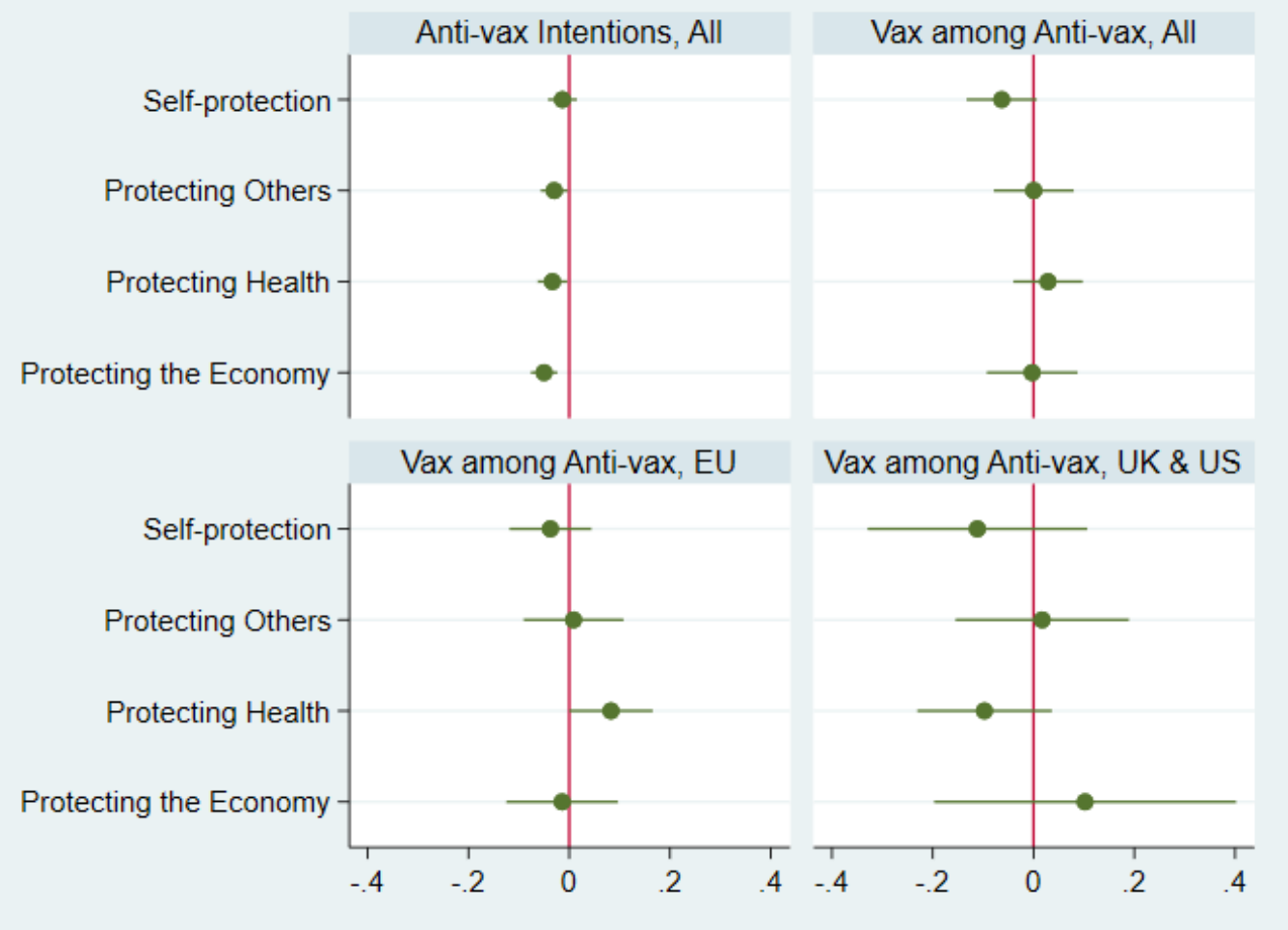

Point estimates and 95\% confidence intervals for each of the four treatments (Self-protection, Protecting Others, Protecting Health, and Protecting the Economy), from regressions using pooled data and the outcome variables "Anti-vax" (upper left panel) and "Vaccination" (other panels) and also controlling for country fixed effects. We restrict the sample to individuals with Anti-vax intentions (upper right panel), individuals with Anti-vax intentions in EU countries (lower left panel) and individuals with Anti-vax intentions in the U.K. and U.S. (lower right panel). 


\section{Supplementary Materials:}

Methods

Table S1: Mortality and Vaccination Statistics

Table S2: Dates of the Survey's First and Second Waves

Table S3: Summary Statistics

Table S4: Determinants of Vaccination Intentions

Table S5: Determinants of Anti-vax Intentions

Table S6: Determinants of Vaccinations

Table S7: Determinants of Vaccinations among Anti-Vax

Table S8: Balance Tests

Table S9: Effects of Experimental Treatments

\section{Methods}

To estimate the effect of our explanatory variables on our outcomes of interest ("Vaccination Intentions", “Anti-vax Intentions”, and "Vaccination”), we use OLS estimates of the following linear equation:

$$
y_{i c}=\alpha+\gamma X_{i c}+\delta Z_{i c}+\rho C_{i c}+\beta F_{c}+\mu I_{i c}+\varepsilon_{i c}
$$

where $y_{i c}$ is an outcome of interest for individual $i$ in country $c, X_{i c}$ is the vector of control variables that capture the individual sociodemographic factors (age groups, education, occupation status, and gender), $Z_{i c}$ is the vector of psycho-behavioral characteristics (risk aversion, consumption of traditional and social media, estimated probability of being infected, estimated probability of being serious ill if infected, whether the respondent had COVID, whether a friend or relative had COVID, and political ideology), $C_{i c}$ is the vector of variables capturing confidence in COVID-19 vaccines (COVID-19 was created by large corporations or by China, trust in scientists, belief that there was not enough time to study the vaccines' side effects), $I_{i c}$ is the variable capturing Vaccination Intentions, which is used when the outcome variable is "Vaccination", $F_{c}$ are country fixed effects and $\varepsilon_{i c}$ is the error term. Standard errors are clustered at the region-country level. All explanatory variables are measured in December 2020 in the first wave, except the belief that there was not enough time to study the vaccines' side effects, which was only asked in the June/July 2021 wave. This is to avoid that some perceptions (on COVID or on the vaccines) that we want to study as a determinant of the vaccination decision may actually be affected by the vaccination experience itself.

Results using this specification are reported in Figures 2 and 4 and in Tables S4 to S7.

Figure 2 (left panel) displays the point estimates from a regression of the outcome variable "Vaccination Intentions" on the entire set of explanatory variables, using the full sample. These estimates are also reported in Table S4 (column 1), while columns 2 to 4 report the results for three geographical subsets: EU countries, the U.K. and U.S., and Australia and New Zealand.

Figure 2 (right panel) displays the point estimates from a regression of the outcome variable "Antivax Intentions" on the entire set of explanatory variables, using the full sample. These estimates are also reported in Table S5 (column 1), while columns 4 to 6 report the results for three geographical 
subsets: EU countries, the U.K. and U.S., and Australia and New Zealand. Columns 2 and 3 report the results for two additional outcomes, using the full sample: "Hard Anti-vax Intentions" and "Soft Anti-vax Intentions”.

Figure 4 (left panel) displays the point estimates from a regression of the outcome variable "Vaccination" on the entire set of explanatory variables and on vaccination intentions, using the full sample. These estimates are also reported in Table S6 (column 1), while columns 2 to 4 report the results for three geographical subsets: EU countries, the U.K. and U.S., and Australia and New Zealand.

Finally, Figure 4 (right panel) displays the point estimates from a regression of the outcome variable "Vaccination" on the entire set of explanatory variables, for the sample of individuals with Anti-vax intentions only. These estimates are also reported in Table S7 (column 1), while columns 2 to 4 report the results for three geographical subsets: EU countries, the U.K. and U.S., and Australia and New Zealand.

To estimate the impact of our informational treatments on COVID-19 vaccination, we run the following linear equation:

$$
y_{i c}=\alpha+\mu E_{i c}+\beta F_{c}+\varepsilon_{i c},
$$

where $y_{i c}$ is the outcome variable ("Vaccination Intentions", “Anti-vax Intentions”, and "Vaccination"), $E_{i c}$ is the vector that captures the four informational treatments, $F_{c}$ are country fixed effects, and $\varepsilon_{i c}$ is the error term. Standard errors are clustered at the region-country level.

Results of this specification are reported in Figures 5 and 6 and in Tables S8 and S9.

Table S8 reports the balance tests for the personal characteristics of the survey participants across the four experimental treatments. They represent the results of separate linear regression of the covariates in the vectors $X_{i c}, Z_{i c}$, and $C_{i c}$ on the four treatments (Self-protection, Protecting Others, Protecting Health, and Protecting the Economy).

Figure 5 displays the point estimates from regressions of the outcome variables "Vaccination Intentions" (upper left panel) and "Vaccination" (upper right panel and lower panels) on the four treatments (Self-protection, Protecting Others, Protecting Health, and Protecting the Economy) and on country fixed effects. We use the full sample in the upper panels and restrict the sample to EU countries and to the U.K. and U.S. in the lower panels. These results as well as the results for Australia and New Zealand are also reported in Table S9 (columns 1-5).

Figure 6 displays the point estimates from regressions of the outcome variables "Anti-vax Intentions" (upper left panel) and "Vaccination" (upper right panel and lower panels), on the four treatments (Self-protection, Protecting Others, Protecting Health, and Protecting the Economy) and on country fixed effects. We use the full sample in the upper left panel, the sample of individuals with anti-vax intentions in the upper right panel, and restrict the sample to individuals with anti-vax intentions in EU countries and in the U.K. and U.S. in the lower panels. These results as well as the results for individuals with anti-vax intentions in Australia and New Zealand are also reported in Table S9 (columns 6-10). 
Table S1. Mortality and Vaccination Statistics

\begin{tabular}{|c|c|c|c|c|c|}
\hline & $\begin{array}{l}\text { Mortality } \\
\text { Rate }\end{array}$ & $\begin{array}{c}\text { Vaccination } \\
\text { Rate }\end{array}$ & $\begin{array}{l}\text { Vaccination } \\
\text { Starting Date }\end{array}$ & $\begin{array}{l}\text { Open-to-all- } \\
\text { adult Date }\end{array}$ & $\begin{array}{l}\text { Groups with } \\
\text { Vaccination } \\
\text { Mandate }\end{array}$ \\
\hline Australia & 3.6 & $23.7 \%$ & February 2021 & August 2021 & $\begin{array}{l}\text { Healthcare workers; } \\
70+; 40+. \\
\text { Healthcare staff \& }\end{array}$ \\
\hline Austria & 68.5 & $53.2 \%$ & January 2021 & May 2021 & $\begin{array}{l}80+; \text { selected } \\
\text { workers \& 65+. }\end{array}$ \\
\hline France & 93.6 & $50.8 \%$ & $\begin{array}{c}\text { December } \\
2020\end{array}$ & June 2021 & $\begin{array}{l}\text { Care givers } 50+; 75+; \\
65+; 50+\& \text { with co- } \\
\text { morbidities. }\end{array}$ \\
\hline Germany & 36.1 & $55.3 \%$ & $\begin{array}{l}\text { December } \\
2020\end{array}$ & June 2021 & $\begin{array}{l}\text { Medical personnel \& } \\
80+; 70+\& \text { with } \\
\text { preconditions; } 60+.\end{array}$ \\
\hline Italy & 118.5 & $57 \%$ & $\begin{array}{l}\text { December } \\
2020\end{array}$ & June 2021 & $\begin{array}{l}\text { Healthcare workers } \\
\& 80+; 70+; 60+\& \\
\text { with co-morbidities. }\end{array}$ \\
\hline $\begin{array}{l}\text { New } \\
\text { Zealand }\end{array}$ & 0.5 & $14.1 \%$ & February 2021 & July 2021 & $\begin{array}{l}\text { Healthcare workers; } \\
65+\& \text { with } \\
\text { preconditions. }\end{array}$ \\
\hline Sweden & 81.3 & $48.5 \%$ & $\begin{array}{l}\text { December } \\
2020\end{array}$ & July 2021 & $\begin{array}{l}\text { Healthcare workers; } \\
65+\text {; people with } \\
\text { preconditions, } 55+\text {. }\end{array}$ \\
\hline U.K. & 106.5 & $65.8 \%$ & $\begin{array}{l}\text { December } \\
2020\end{array}$ & $\begin{array}{c}\text { February } \\
2021\end{array}$ & $\begin{array}{l}\text { Healthcare workers } \\
\& 50+.\end{array}$ \\
\hline U.S. & 101.5 & $54.7 \%$ & $\begin{array}{c}\text { December } \\
2020\end{array}$ & April 2021 & \\
\hline
\end{tabular}

Note: Mortality rates measure deaths per 100,000 inhabitants on 28 December 2020, from https://coronavirus.jhu.edu/data/mortality. Vaccination rates are the ratio of people who received at least one vaccination over the total population on 30 June 2021, from https://ourworldindata.org/covid-vaccinations. 
Table S2. Dates of the Survey's First and Second Waves

$\begin{array}{ccc}\text { Dates } & \text { Dates } & \\ \text { of the Survey's } & \text { of the Survey's } & \text { Number of Respondents } \\ \text { First Wave } & \text { Second Wave } & \text { Surveyed in Both Waves }\end{array}$

\begin{tabular}{lccc}
\hline Australia & 4-10 December 2020 & June 28-July 8, 2021 & 343 \\
Austria & 5-9 December 2020 & July 1-July 13, 2021 & 324 \\
France & 2-5 December 2020 & June 29-July 8, 2021 & 850 \\
Germany & 5-9 December 2020 & June 30-July 7, 2021 & 1481 \\
Italy & 5-7 December 2020 & June 29-July 6, 2021 & 710 \\
New Zealand & 5-9 December 2020 & June 29-July 10, 2021 & 639 \\
Sweden & 5-9 December 2020 & June 30-July 8, 2021 & 693 \\
U.K. & 5-8 December 2020 & June 29-July 9, 2021 & 697 \\
U.S. & 4-11 December 2020 & June 28-July 8, 2021 & 642 \\
\hline
\end{tabular}


Table S3. Summary Statistics

\begin{tabular}{|c|c|c|c|c|c|}
\hline VARIABLES & Obs & Mean & Std. dev. & Min & Max \\
\hline $18-34$ yo & 6379 & 0.17 & 0.38 & 0 & 1 \\
\hline $35-49$ yo & 6379 & 0.27 & 0.44 & 0 & 1 \\
\hline $50-59$ yo & 6379 & 0.19 & 0.4 & 0 & 1 \\
\hline $65+$ & 6379 & 0.36 & 0.48 & 0 & 1 \\
\hline Women & 6379 & 0.49 & 0.5 & 0 & 1 \\
\hline White collars workers & 6379 & 0.17 & 0.37 & 0 & 1 \\
\hline Service workers & 6379 & 0.31 & 0.46 & 0 & 1 \\
\hline Blue collars workers & 6379 & 0.14 & 0.35 & 0 & 1 \\
\hline Inactive & 6379 & 0.38 & 0.49 & 0 & 1 \\
\hline High school & 6379 & 0.52 & 0.5 & 0 & 1 \\
\hline College & 6379 & 0.39 & 0.49 & 0 & 1 \\
\hline Media Info & 6379 & 0.58 & 0.22 & 0,2 & 1 \\
\hline Social Info & 6371 & 0.51 & 0.32 & 0,2 & 1 \\
\hline Compliance & 6379 & 0.74 & 0.22 & 0 & 1 \\
\hline Live w/family & 6379 & 0.64 & 0.48 & 0 & 1 \\
\hline COVID & 6379 & 0.04 & 0.2 & 0 & 1 \\
\hline Others w/COVID & 6379 & 0.24 & 0.43 & 0 & 1 \\
\hline Prob COVID & 6379 & 0.52 & 0.29 & 0 & 1 \\
\hline Prob Seriously III & 6379 & 0.55 & 0.28 & 0 & 1 \\
\hline Live w/Family & 6379 & 0.64 & 0.48 & 0 & 1 \\
\hline Conservative & 6379 & 0.24 & 0.43 & 0 & 1 \\
\hline Centrist & 6379 & 0.45 & 0.5 & 0 & 1 \\
\hline Liberal & 6379 & 0.22 & 0.41 & 0 & 1 \\
\hline Undeclared Ideology & 6379 & 0.09 & 0.28 & 0 & 1 \\
\hline Trust in Scientists & 6378 & 0.84 & 0.37 & 0 & 1 \\
\hline Risk Aversion & 6252 & 0.57 & 0.26 & 0 & 1 \\
\hline Big Pharma's Fault & 6275 & 0.26 & 0.32 & 0 & 1 \\
\hline China's Fault & 6253 & 0.32 & 0.34 & 0 & 1 \\
\hline Vaccines' Side Effects & 6379 & 0.51 & 0.31 & 0 & 1 \\
\hline Vaccination Intentions & 6379 & 0.65 & 0.34 & 0 & 1 \\
\hline Self-protection & 6379 & 0.2 & 0.4 & 0 & 1 \\
\hline Protecting Others & 6379 & 0.2 & 0.4 & 0 & 1 \\
\hline Protecting Own Country & 6379 & 0.2 & 0.4 & 0 & 1 \\
\hline Protecting the Economy & 6379 & 0.2 & 0.4 & 0 & 1 \\
\hline
\end{tabular}


Table S4. Determinants of Vaccination Intentions

\begin{tabular}{|c|c|c|c|c|}
\hline & (1) & (2) & (3) & (4) \\
\hline VARIABLES & All & EU & UK \& US & AUS \& NZ \\
\hline \multirow[t]{2}{*}{$35-49$ yo } & $-0.034 * * *$ & $-0.046 * * *$ & -0.019 & 0.006 \\
\hline & {$[0.012]$} & [0.015] & {$[0.029]$} & {$[0.023]$} \\
\hline \multirow[t]{2}{*}{$50-59$ yo } & -0.005 & -0.004 & 0.025 & -0.045 \\
\hline & {$[0.014]$} & {$[0.018]$} & {$[0.027]$} & {$[0.035]$} \\
\hline \multirow[t]{2}{*}{$60+$} & 0.014 & 0.001 & 0.052 & -0.018 \\
\hline & {$[0.013]$} & {$[0.017]$} & [0.031] & {$[0.026]$} \\
\hline \multirow[t]{2}{*}{ Women } & $-0.062 * * *$ & $-0.075^{* * *}$ & $-0.041 * *$ & -0.035 \\
\hline & [0.008] & [0.009] & {$[0.016]$} & {$[0.026]$} \\
\hline \multirow[t]{2}{*}{ High school } & 0.004 & -0.006 & 0.127 & 0.017 \\
\hline & {$[0.016]$} & {$[0.021]$} & {$[0.110]$} & {$[0.023]$} \\
\hline \multirow[t]{2}{*}{ College } & 0.018 & 0.010 & 0.148 & 0.020 \\
\hline & {$[0.017]$} & {$[0.023]$} & {$[0.105]$} & {$[0.025]$} \\
\hline \multirow[t]{2}{*}{ Service workers } & $-0.018 *$ & -0.021 & $-0.030 *$ & 0.024 \\
\hline & {$[0.010]$} & {$[0.014]$} & {$[0.014]$} & {$[0.023]$} \\
\hline \multirow{2}{*}{ Blue collar workers } & $-0.039 * * *$ & $-0.042 * *$ & $-0.049 * * *$ & -0.008 \\
\hline & [0.012] & [0.019] & [0.011] & [0.031] \\
\hline \multirow[t]{2}{*}{ Inactive } & -0.015 & -0.009 & -0.037 & -0.016 \\
\hline & {$[0.012]$} & [0.018] & {$[0.025]$} & [0.024] \\
\hline \multirow[t]{2}{*}{ Traditional media consumption } & $0.164 * * *$ & $0.167^{* * *}$ & $0.117 * * *$ & $0.177^{* * *}$ \\
\hline & {$[0.016]$} & [0.020] & [0.025] & [0.045] \\
\hline \multirow[t]{2}{*}{ Social media consumption } & -0.008 & -0.003 & -0.002 & -0.035 \\
\hline & {$[0.010]$} & [0.012] & {$[0.025]$} & {$[0.024]$} \\
\hline \multirow[t]{2}{*}{ Compliance } & $0.216^{* * *}$ & $0.224 * * *$ & $0.340 * * *$ & $0.130 * * *$ \\
\hline & [0.027] & [0.036] & [0.059] & [0.045] \\
\hline \multirow[t]{2}{*}{ Live w/family } & 0.002 & 0.009 & -0.013 & -0.014 \\
\hline & {$[0.006]$} & {$[0.008]$} & {$[0.011]$} & {$[0.018]$} \\
\hline \multirow[t]{2}{*}{ COVID } & $-0.036^{*}$ & -0.039 & -0.018 & -0.029 \\
\hline & {$[0.020]$} & {$[0.028]$} & {$[0.042]$} & {$[0.029]$} \\
\hline \multirow[t]{2}{*}{ Others w/COVID } & 0.007 & 0.010 & 0.025 & $-0.083 * *$ \\
\hline & {$[0.008]$} & [0.009] & {$[0.018]$} & [0.038] \\
\hline \multirow[t]{2}{*}{ Prob COVID } & $0.056 * * *$ & $0.037^{*}$ & 0.071 & 0.012 \\
\hline & [0.019] & {$[0.020]$} & {$[0.042]$} & {$[0.055]$} \\
\hline \multirow[t]{2}{*}{ Prob seriously ill } & $0.188 * * *$ & $0.228 * * *$ & $0.095 * * *$ & $0.209 * * *$ \\
\hline & {$[0.021]$} & {$[0.027]$} & {$[0.030]$} & {$[0.036]$} \\
\hline \multirow[t]{2}{*}{ Conservative } & -0.005 & $-0.021^{*}$ & -0.003 & $0.066^{*}$ \\
\hline & [0.012] & [0.012] & [0.032] & {$[0.033]$} \\
\hline \multirow[t]{2}{*}{ Undeclared ideology } & $-0.056 * * *$ & $-0.058 * * *$ & $-0.051 * * *$ & $-0.068 * *$ \\
\hline & [0.014] & {$[0.020]$} & [0.013] & [0.029] \\
\hline \multirow[t]{2}{*}{ Trust in scientists } & $0.127^{* * *}$ & $0.118^{* * *}$ & $0.175^{* * *}$ & $0.121 * * *$ \\
\hline & [0.010] & [0.012] & {$[0.030]$} & [0.030] \\
\hline Risk aversion & -0.019 & -0.007 & -0.016 & $-0.063 * *$ \\
\hline & {$[0.013]$} & [0.018] & {$[0.029]$} & [0.027] \\
\hline Big pharma's fault & $-0.114 * * *$ & $-0.116 * * *$ & $-0.078^{*}$ & $-0.134 * * *$ \\
\hline & [0.020] & [0.029] & {$[0.037]$} & [0.044] \\
\hline China's fault & -0.004 & -0.012 & 0.027 & -0.000 \\
\hline & {$[0.018]$} & {$[0.027]$} & {$[0.025]$} & {$[0.040]$} \\
\hline Vaccines' side effects & $-0.311 * * *$ & $-0.304 * * *$ & $-0.248 * * *$ & $-0.398 * * *$ \\
\hline & [0.014] & [0.017] & [0.025] & [0.027] \\
\hline Observations & 6,072 & 3,930 & 1,229 & 913 \\
\hline R-squared & 0.383 & 0.375 & 0.393 & 0.321 \\
\hline Country FE & Yes & Yes & Yes & Yes \\
\hline Mean outcome variable & 0.649 & 0.604 & 0.751 & 0.705 \\
\hline
\end{tabular}


Table S5. Determinants of Anti-vax Intentions

\begin{tabular}{|c|c|c|c|c|c|c|}
\hline VARIABLES & $\begin{array}{c}(1) \\
\text { Anti-vax } \\
\text { All }\end{array}$ & $\begin{array}{c}\text { (2) } \\
\text { Hard Anti-vax } \\
\text { All }\end{array}$ & $\begin{array}{c}(3) \\
\text { Soft Anti-vax } \\
\text { All }\end{array}$ & $\begin{array}{c}(4) \\
\text { Anti-vax } \\
\text { EU }\end{array}$ & $\begin{array}{c}\text { (5) } \\
\text { Anti-vax } \\
\text { UK \& US }\end{array}$ & $\begin{array}{c}\text { (6) } \\
\text { Anti-vax } \\
\text { AUS \& NZ }\end{array}$ \\
\hline $35-49$ yo & $\begin{array}{c}0.048 * * * \\
{[0.013]}\end{array}$ & $\begin{array}{c}0.040^{* * *} \\
{[0.010]}\end{array}$ & $\begin{array}{c}0.008 \\
{[0.011]}\end{array}$ & $\begin{array}{c}0.053^{* * *} \\
{[0.017]}\end{array}$ & $\begin{array}{c}0.035 \\
{[0.029]}\end{array}$ & $\begin{array}{c}0.040 \\
{[0.028]}\end{array}$ \\
\hline $50-59$ yo & $\begin{array}{c}0.057 * * * \\
{[0.018]}\end{array}$ & $\begin{array}{c}0.049 * * * \\
{[0.012]}\end{array}$ & $\begin{array}{c}0.007 \\
{[0.014]}\end{array}$ & $\begin{array}{l}0.054^{* *} \\
{[0.023]}\end{array}$ & $\begin{array}{c}0.034 \\
{[0.028]}\end{array}$ & $\begin{array}{l}0.094^{*} \\
{[0.053]}\end{array}$ \\
\hline $60+$ & $\begin{array}{c}0.059 * * * \\
{[0.016]}\end{array}$ & $\begin{array}{c}0.051 * * * \\
{[0.012]}\end{array}$ & $\begin{array}{c}0.007 \\
{[0.012]}\end{array}$ & $\begin{array}{c}0.068^{* * *} \\
{[0.022]}\end{array}$ & $\begin{array}{c}0.021 \\
{[0.033]}\end{array}$ & $\begin{array}{c}0.097 * * * \\
{[0.033]}\end{array}$ \\
\hline Women & $\begin{array}{c}0.059 * * * \\
{[0.009]}\end{array}$ & $\begin{array}{c}0.024^{* * *} \\
{[0.008]}\end{array}$ & $\begin{array}{c}0.035 * * * \\
{[0.008]}\end{array}$ & $\begin{array}{c}0.069 * * * \\
{[0.013]}\end{array}$ & $\begin{array}{l}0.037^{* *} \\
{[0.012]}\end{array}$ & $\begin{array}{l}0.044^{*} \\
{[0.024]}\end{array}$ \\
\hline High school & $\begin{array}{c}0.022 \\
{[0.020]}\end{array}$ & $\begin{array}{c}-0.004 \\
{[0.015]}\end{array}$ & $\begin{array}{c}0.026 \\
{[0.018]}\end{array}$ & $\begin{array}{c}0.035 \\
{[0.027]}\end{array}$ & $\begin{array}{l}-0.212 \\
{[0.128]}\end{array}$ & $\begin{array}{c}0.013 \\
{[0.028]}\end{array}$ \\
\hline College & $\begin{array}{c}0.017 \\
{[0.021]}\end{array}$ & $\begin{array}{l}-0.006 \\
{[0.015]}\end{array}$ & $\begin{array}{c}0.023 \\
{[0.019]}\end{array}$ & $\begin{array}{c}0.034 \\
{[0.028]}\end{array}$ & $\begin{array}{l}-0.224^{*} \\
{[0.119]}\end{array}$ & $\begin{array}{c}0.005 \\
{[0.029]}\end{array}$ \\
\hline Service workers & $\begin{array}{c}0.018 \\
{[0.013]}\end{array}$ & $\begin{array}{c}0.015 \\
{[0.010]}\end{array}$ & $\begin{array}{c}0.002 \\
{[0.012]}\end{array}$ & $\begin{array}{c}0.028 \\
{[0.018]}\end{array}$ & $\begin{array}{c}0.019 \\
{[0.016]}\end{array}$ & $\begin{array}{c}-0.024 \\
{[0.028]}\end{array}$ \\
\hline Blue collar workers & $\begin{array}{c}0.046 * * * \\
{[0.015]}\end{array}$ & $\begin{array}{c}0.013 \\
{[0.012]}\end{array}$ & $\begin{array}{c}0.033^{* *} \\
{[0.015]}\end{array}$ & $\begin{array}{l}0.056^{* *} \\
{[0.024]}\end{array}$ & $\begin{array}{l}0.040^{*} \\
{[0.022]}\end{array}$ & $\begin{array}{c}0.016 \\
{[0.035]}\end{array}$ \\
\hline Inactive & $\begin{array}{c}0.020 \\
{[0.014]}\end{array}$ & $\begin{array}{c}0.012 \\
{[0.009]}\end{array}$ & $\begin{array}{c}0.007 \\
{[0.013]}\end{array}$ & $\begin{array}{c}0.016 \\
{[0.021]}\end{array}$ & $\begin{array}{c}0.055^{* *} \\
{[0.019]}\end{array}$ & $\begin{array}{c}0.015 \\
{[0.032]}\end{array}$ \\
\hline Traditional media consumption & $\begin{array}{c}-0.186^{* * *} \\
{[0.022]}\end{array}$ & $\begin{array}{c}-0.141 * * * \\
{[0.022]}\end{array}$ & $\begin{array}{c}-0.046^{* *} \\
{[0.021]}\end{array}$ & $\begin{array}{c}-0.196 * * * \\
{[0.028]}\end{array}$ & $\begin{array}{c}-0.103^{* *} \\
{[0.035]}\end{array}$ & $\begin{array}{c}-0.209 * * * \\
{[0.054]}\end{array}$ \\
\hline Social media consumption & $\begin{array}{c}-0.006 \\
{[0.017]}\end{array}$ & $\begin{array}{c}0.001 \\
{[0.010]}\end{array}$ & $\begin{array}{l}-0.007 \\
{[0.018]}\end{array}$ & $\begin{array}{l}-0.006 \\
{[0.021]}\end{array}$ & $\begin{array}{l}-0.053 \\
{[0.035]}\end{array}$ & $\begin{array}{c}0.063 \\
{[0.045]}\end{array}$ \\
\hline Compliance & $\begin{array}{c}-0.187 * * * \\
{[0.038]}\end{array}$ & $\begin{array}{c}-0.183 * * * \\
{[0.031]}\end{array}$ & $\begin{array}{c}-0.004 \\
{[0.021]}\end{array}$ & $\begin{array}{c}-0.183 * * * \\
{[0.057]}\end{array}$ & $\begin{array}{c}-0.288 * * * \\
{[0.055]}\end{array}$ & $\begin{array}{c}-0.164 * * * \\
{[0.048]}\end{array}$ \\
\hline Live w/family & $\begin{array}{l}-0.005 \\
{[0.008]}\end{array}$ & $\begin{array}{l}-0.000 \\
{[0.008]}\end{array}$ & $\begin{array}{l}-0.004 \\
{[0.006]}\end{array}$ & $\begin{array}{l}-0.010 \\
{[0.011]}\end{array}$ & $\begin{array}{c}0.001 \\
{[0.014]}\end{array}$ & $\begin{array}{c}0.007 \\
{[0.024]}\end{array}$ \\
\hline COVID & $\begin{array}{c}0.040 \\
{[0.024]}\end{array}$ & $\begin{array}{c}0.019 \\
{[0.023]}\end{array}$ & $\begin{array}{c}0.021 \\
{[0.017]}\end{array}$ & $\begin{array}{c}0.038 \\
{[0.034]}\end{array}$ & $\begin{array}{c}0.043 \\
{[0.048]}\end{array}$ & $\begin{array}{c}0.022 \\
{[0.041]}\end{array}$ \\
\hline Others w/COVID & $\begin{array}{l}-0.014 \\
{[0.011]}\end{array}$ & $\begin{array}{c}-0.000 \\
{[0.008]}\end{array}$ & $\begin{array}{l}-0.013 \\
{[0.008]}\end{array}$ & $\begin{array}{l}-0.018 \\
{[0.013]}\end{array}$ & $\begin{array}{l}-0.022 \\
{[0.017]}\end{array}$ & $\begin{array}{c}0.044 \\
{[0.044]}\end{array}$ \\
\hline Prob COVID & $\begin{array}{c}-0.069 * * * \\
{[0.023]}\end{array}$ & $\begin{array}{c}-0.069 * * * \\
{[0.018]}\end{array}$ & $\begin{array}{c}0.000 \\
{[0.016]}\end{array}$ & $\begin{array}{l}-0.047^{*} \\
{[0.028]}\end{array}$ & $\begin{array}{c}-0.042 \\
{[0.051]}\end{array}$ & $\begin{array}{l}-0.059 \\
{[0.060]}\end{array}$ \\
\hline Prob seriously ill & $\begin{array}{c}-0.226 * * * \\
{[0.022]}\end{array}$ & $\begin{array}{c}-0.121 * * * \\
{[0.019]}\end{array}$ & $\begin{array}{c}-0.105^{* * *} \\
{[0.017]}\end{array}$ & $\begin{array}{c}-0.276 * * * \\
{[0.030]}\end{array}$ & $\begin{array}{c}-0.152 * * * \\
{[0.038]}\end{array}$ & $\begin{array}{c}-0.204 * * * \\
{[0.040]}\end{array}$ \\
\hline Conservative & $\begin{array}{c}0.024 \\
{[0.016]}\end{array}$ & $\begin{array}{c}0.037 * * * \\
{[0.011]}\end{array}$ & $\begin{array}{l}-0.014 \\
{[0.010]}\end{array}$ & $\begin{array}{c}0.037 * * \\
{[0.018]}\end{array}$ & $\begin{array}{c}0.035 \\
{[0.032]}\end{array}$ & $\begin{array}{l}-0.052 \\
{[0.045]}\end{array}$ \\
\hline Undeclared ideology & $\begin{array}{c}0.045^{* *} \\
{[0.019]}\end{array}$ & $\begin{array}{c}0.023 \\
{[0.014]}\end{array}$ & $\begin{array}{c}0.022 \\
{[0.015]}\end{array}$ & $\begin{array}{c}0.040 \\
{[0.029]}\end{array}$ & $\begin{array}{c}0.055^{* *} \\
{[0.020]}\end{array}$ & $\begin{array}{c}0.049 \\
{[0.040]}\end{array}$ \\
\hline Trust in scientists & $\begin{array}{c}-0.156^{* * *} \\
{[0.016]}\end{array}$ & $\begin{array}{c}-0.132 * * * \\
{[0.013]}\end{array}$ & $\begin{array}{l}-0.024^{*} \\
{[0.012]}\end{array}$ & $\begin{array}{c}-0.152^{* * *} \\
{[0.019]}\end{array}$ & $\begin{array}{c}-0.203^{* * *} \\
{[0.041]}\end{array}$ & $\begin{array}{c}-0.128^{* *} \\
{[0.056]}\end{array}$ \\
\hline Risk aversion & $\begin{array}{c}0.040 * * \\
{[0.019]}\end{array}$ & $\begin{array}{c}0.024 \\
{[0.015]}\end{array}$ & $\begin{array}{c}0.016 \\
{[0.015]}\end{array}$ & $\begin{array}{c}0.027 \\
{[0.027]}\end{array}$ & $\begin{array}{c}0.019 \\
{[0.040]}\end{array}$ & $\begin{array}{c}0.115^{* * *} \\
{[0.038]}\end{array}$ \\
\hline Big pharma's fault & $\begin{array}{c}0.072 * * * \\
{[0.026]}\end{array}$ & $\begin{array}{c}0.080 * * * \\
{[0.020]}\end{array}$ & $\begin{array}{l}-0.008 \\
{[0.017]}\end{array}$ & $\begin{array}{l}0.073^{*} \\
{[0.039]}\end{array}$ & $\begin{array}{c}0.034 \\
{[0.045]}\end{array}$ & $\begin{array}{c}0.113^{* *} \\
{[0.052]}\end{array}$ \\
\hline China's fault & $\begin{array}{l}-0.017 \\
{[0.023]}\end{array}$ & $\begin{array}{c}-0.045^{* *} \\
{[0.019]}\end{array}$ & $\begin{array}{l}0.028^{*} \\
{[0.015]}\end{array}$ & $\begin{array}{c}-0.021 \\
{[0.036]}\end{array}$ & $\begin{array}{c}-0.026 \\
{[0.027]}\end{array}$ & $\begin{array}{c}-0.008 \\
{[0.043]}\end{array}$ \\
\hline Vaccines' side effects & $\begin{array}{c}0.337 * * * \\
{[0.020]}\end{array}$ & $\begin{array}{c}0.222 * * * \\
{[0.016]}\end{array}$ & $\begin{array}{c}0.116 * * * \\
{[0.017]}\end{array}$ & $\begin{array}{c}0.355^{* * *} \\
{[0.026]}\end{array}$ & $\begin{array}{c}0.232 * * * \\
{[0.036]}\end{array}$ & $\begin{array}{c}0.391 * * * \\
{[0.038]}\end{array}$ \\
\hline Observations & 6,072 & 6,072 & 6,072 & 3,930 & 1,229 & 913 \\
\hline R-squared & 0.261 & 0.228 & 0.052 & 0.253 & 0.294 & 0.234 \\
\hline Country FE & Yes & Yes & Yes & Yes & Yes & Yes \\
\hline Mean outcome variable & 0.212 & 0.107 & 0.105 & 0.250 & 0.128 & 0.158 \\
\hline
\end{tabular}


Table S6. Determinants of Vaccinations

\begin{tabular}{|c|c|c|c|c|}
\hline & (1) & (2) & $(3)$ & $(4)$ \\
\hline VARIABLES & All & EU & UK \& US & AS \& NZ \\
\hline \multirow[t]{2}{*}{ Vaccination Intentions } & $0.298^{* * *}$ & $0.302 * * *$ & $0.364^{* * *}$ & $0.175^{* * *}$ \\
\hline & [0.019] & {$[0.024]$} & {$[0.036]$} & [0.040] \\
\hline \multirow[t]{2}{*}{$35-49$ yo } & $0.094 * * *$ & $0.103^{* * *}$ & $0.084 * * *$ & 0.066 \\
\hline & {$[0.020]$} & [0.029] & {$[0.022]$} & {$[0.041]$} \\
\hline \multirow[t]{2}{*}{$50-59$ yo } & $0.156^{* * *}$ & $0.174 * * *$ & $0.119 * * *$ & $0.134 * *$ \\
\hline & {$[0.024]$} & [0.032] & {$[0.020]$} & {$[0.062]$} \\
\hline \multirow[t]{2}{*}{$60+$} & $0.216^{* * *}$ & $0.230 * * *$ & $0.115^{* * *}$ & $0.293 * * *$ \\
\hline & {$[0.021]$} & {$[0.026]$} & {$[0.027]$} & [0.072] \\
\hline \multirow[t]{2}{*}{ Women } & -0.007 & 0.003 & $-0.029 *$ & -0.010 \\
\hline & {$[0.010]$} & {$[0.012]$} & {$[0.014]$} & {$[0.025]$} \\
\hline \multirow[t]{2}{*}{ High school } & 0.006 & 0.013 & 0.145 & 0.009 \\
\hline & {$[0.021]$} & {$[0.028]$} & [0.173] & [0.033] \\
\hline \multirow[t]{2}{*}{ College } & 0.019 & 0.031 & 0.169 & -0.009 \\
\hline & {$[0.022]$} & [0.029] & {$[0.160]$} & {$[0.041]$} \\
\hline \multirow[t]{2}{*}{ Service workers } & -0.017 & -0.001 & -0.013 & $-0.090 * *$ \\
\hline & {$[0.015]$} & [0.023] & {$[0.020]$} & [0.035] \\
\hline \multirow[t]{2}{*}{ Blue collar workers } & $-0.047^{* *}$ & $-0.048^{*}$ & -0.027 & $-0.096 * * *$ \\
\hline & {$[0.018]$} & {$[0.027]$} & {$[0.023]$} & [0.032] \\
\hline \multirow[t]{2}{*}{ Inactive } & $-0.060 * * *$ & $-0.047^{*}$ & $-0.077 * * *$ & $-0.142 * * *$ \\
\hline & [0.017] & {$[0.024]$} & {$[0.023]$} & [0.045] \\
\hline \multirow[t]{2}{*}{ Traditional media consumption } & $0.083 * * *$ & $0.087 * * *$ & 0.043 & 0.079 \\
\hline & {$[0.025]$} & {$[0.030]$} & {$[0.048]$} & {$[0.079]$} \\
\hline \multirow[t]{2}{*}{ Social media consumption } & 0.007 & 0.001 & -0.014 & 0.070 \\
\hline & {$[0.018]$} & {$[0.022]$} & {$[0.028]$} & {$[0.045]$} \\
\hline \multirow[t]{2}{*}{ Compliance } & $0.078 * *$ & $0.084 * *$ & $0.131 * *$ & 0.018 \\
\hline & {$[0.031]$} & {$[0.038]$} & {$[0.045]$} & {$[0.060]$} \\
\hline \multirow[t]{2}{*}{ Live w/family } & $0.022 * *$ & $0.027 * *$ & 0.019 & -0.013 \\
\hline & {$[0.010]$} & {$[0.013]$} & [0.019] & [0.029] \\
\hline \multirow[t]{2}{*}{ COVID } & -0.009 & $-0.046^{*}$ & 0.020 & $0.119 * *$ \\
\hline & {$[0.024]$} & {$[0.027]$} & [0.039] & {$[0.054]$} \\
\hline \multirow[t]{2}{*}{ Others w/COVID } & $0.045^{* * *}$ & $0.059 * * *$ & 0.018 & $-0.083 * * *$ \\
\hline & {$[0.012]$} & [0.015] & {$[0.017]$} & [0.028] \\
\hline \multirow[t]{2}{*}{ Prob COVID } & $0.042 *$ & 0.003 & $0.075^{* *}$ & -0.015 \\
\hline & {$[0.023]$} & {$[0.034]$} & {$[0.031]$} & [0.077] \\
\hline \multirow[t]{2}{*}{ Prob seriously ill } & $0.058 * *$ & $0.099 * *$ & 0.025 & 0.013 \\
\hline & {$[0.026]$} & {$[0.038]$} & {$[0.025]$} & {$[0.061]$} \\
\hline \multirow[t]{2}{*}{ Conservative } & 0.007 & 0.013 & $-0.051 * * *$ & $0.074 *$ \\
\hline & {$[0.012]$} & [0.013] & {$[0.014]$} & [0.039] \\
\hline \multirow[t]{2}{*}{ Undeclared ideology } & 0.002 & -0.025 & $0.061 * *$ & 0.025 \\
\hline & [0.023] & [0.033] & {$[0.024]$} & {$[0.045]$} \\
\hline Trust in scientists & $0.033^{*}$ & 0.008 & $0.089 * * *$ & $0.076 * *$ \\
\hline & {$[0.020]$} & {$[0.025]$} & [0.023] & {$[0.035]$} \\
\hline Risk aversion & -0.024 & -0.035 & -0.023 & 0.043 \\
\hline & [0.019] & {$[0.026]$} & [0.032] & {$[0.036]$} \\
\hline Big pharma's fault & $-0.074 * * *$ & $-0.097 * * *$ & -0.052 & -0.014 \\
\hline & [0.022] & [0.029] & [0.033] & {$[0.062]$} \\
\hline China's fault & 0.021 & 0.034 & 0.049 & -0.031 \\
\hline & {$[0.021]$} & {$[0.028]$} & {$[0.043]$} & {$[0.046]$} \\
\hline Vaccines' side effects & $-0.204 * * *$ & $-0.220 * * *$ & $-0.175 * * *$ & $-0.157 * * *$ \\
\hline & [0.017] & [0.019] & [0.037] & [0.053] \\
\hline Observations & 6,072 & 3,930 & 1,229 & 913 \\
\hline
\end{tabular}


R-squared

Country FE

Mean outcome variable
0.349

Yes

0.693
0.238

Yes

0.741
0.344

Yes

0.854
0.167

Yes

0.269 
Table S7. Determinants of Vaccinations among Anti-vax

\begin{tabular}{|c|c|c|c|c|}
\hline & (1) & (2) & (3) & (4) \\
\hline VARIABLES & All & EU & UK \& US & AUS \& NZ \\
\hline \multirow[t]{2}{*}{$35-49$ yo } & 0.040 & -0.014 & $0.323 * * *$ & 0.056 \\
\hline & [0.044] & {$[0.052]$} & [0.078] & {$[0.056]$} \\
\hline \multirow[t]{2}{*}{$50-59$ yо } & $0.111^{* *}$ & $0.092^{*}$ & $0.256^{*}$ & 0.130 \\
\hline & [0.044] & {$[0.051]$} & [0.132] & [0.079] \\
\hline \multirow[t]{2}{*}{$60+$} & $0.098^{* *}$ & 0.063 & $0.220^{*}$ & $0.206 * * *$ \\
\hline & {$[0.046]$} & {$[0.055]$} & [0.110] & [0.065] \\
\hline \multirow[t]{2}{*}{ Women } & -0.002 & 0.015 & -0.001 & -0.062 \\
\hline & {$[0.025]$} & {$[0.026]$} & {$[0.075]$} & {$[0.061]$} \\
\hline \multirow[t]{2}{*}{ High school } & 0.038 & 0.041 & 0.084 & $0.083 * *$ \\
\hline & {$[0.060]$} & {$[0.080]$} & {$[0.187]$} & [0.031] \\
\hline \multirow[t]{2}{*}{ College } & 0.021 & 0.020 & 0.117 & 0.064 \\
\hline & {$[0.063]$} & {$[0.085]$} & [0.162] & {$[0.048]$} \\
\hline \multirow[t]{2}{*}{ Service workers } & 0.017 & 0.046 & -0.068 & -0.052 \\
\hline & {$[0.040]$} & [0.049] & [0.089] & {$[0.100]$} \\
\hline \multirow[t]{2}{*}{ Blue collar workers } & -0.067 & -0.064 & -0.189 & -0.073 \\
\hline & {$[0.046]$} & [0.059] & {$[0.116]$} & {$[0.100]$} \\
\hline \multirow[t]{2}{*}{ Inactive } & 0.014 & 0.047 & $-0.210^{*}$ & -0.071 \\
\hline & [0.047] & [0.057] & [0.101] & [0.130] \\
\hline \multirow[t]{2}{*}{ Traditional media consumption } & $0.221 * * *$ & $0.234^{* * *}$ & $0.474^{*}$ & -0.044 \\
\hline & [0.067] & [0.074] & {$[0.260]$} & [0.178] \\
\hline \multirow[t]{2}{*}{ Social media consumption } & -0.023 & -0.020 & -0.096 & 0.035 \\
\hline & {$[0.042]$} & {$[0.049]$} & [0.137] & [0.112] \\
\hline \multirow{2}{*}{ Compliance } & $0.139 * *$ & $0.172 * * *$ & 0.205 & -0.042 \\
\hline & {$[0.055]$} & {$[0.061]$} & [0.135] & [0.105] \\
\hline \multirow[t]{2}{*}{ Live w/family } & 0.039 & 0.043 & 0.081 & -0.014 \\
\hline & {$[0.030]$} & {$[0.036]$} & {$[0.067]$} & {$[0.052]$} \\
\hline \multirow[t]{2}{*}{ COVID } & -0.065 & -0.077 & -0.192 & 0.176 \\
\hline & {$[0.070]$} & [0.081] & [0.169] & [0.144] \\
\hline \multirow[t]{2}{*}{ Others w/COVID } & $0.061^{*}$ & 0.056 & 0.068 & -0.036 \\
\hline & {$[0.035]$} & {$[0.036]$} & [0.143] & [0.101] \\
\hline \multirow[t]{2}{*}{ Prob COVID } & 0.060 & -0.015 & 0.147 & 0.128 \\
\hline & {$[0.056]$} & {$[0.074]$} & {$[0.148]$} & {$[0.074]$} \\
\hline \multirow[t]{2}{*}{ Prob seriously ill } & $0.143^{* *}$ & $0.199 * *$ & 0.150 & 0.066 \\
\hline & {$[0.061]$} & {$[0.089]$} & {$[0.103]$} & {$[0.047]$} \\
\hline \multirow[t]{2}{*}{ Conservative } & 0.042 & 0.052 & -0.023 & -0.003 \\
\hline & {$[0.033]$} & [0.041] & [0.079] & [0.085] \\
\hline \multirow[t]{2}{*}{ Undeclared ideology } & -0.040 & $-0.137^{* *}$ & 0.263 & 0.105 \\
\hline & {$[0.055]$} & {$[0.060]$} & [0.165] & [0.070] \\
\hline \multirow[t]{2}{*}{ Trust in scientists } & $0.064^{* *}$ & 0.039 & 0.119 & $0.113^{* *}$ \\
\hline & [0.029] & [0.034] & [0.101] & {$[0.042]$} \\
\hline Risk aversion & $-0.112^{* *}$ & $-0.123^{*}$ & -0.123 & -0.048 \\
\hline & [0.050] & [0.063] & [0.127] & {$[0.088]$} \\
\hline Big pharma's fault & $-0.088^{* *}$ & -0.084 & -0.125 & 0.039 \\
\hline & {$[0.042]$} & {$[0.051]$} & {$[0.083]$} & {$[0.070]$} \\
\hline China's fault & -0.002 & 0.018 & 0.064 & $-0.225^{* * *}$ \\
\hline & {$[0.044]$} & {$[0.052]$} & {$[0.162]$} & [0.068] \\
\hline Vaccines' side effects & $-0.384 * * *$ & $-0.431 * * *$ & $-0.302 * *$ & -0.082 \\
\hline & [0.043] & [0.049] & {$[0.126]$} & [0.097] \\
\hline Observations & 1,285 & 984 & 157 & 144 \\
\hline R-squared & 0.219 & 0.178 & 0.338 & 0.221 \\
\hline Country FE & Yes & Yes & Yes & Yes \\
\hline Mean outcome variable & 0.450 & 0.503 & 0.439 & 0.0972 \\
\hline
\end{tabular}


Table S8: Balance Tests (Panel A)

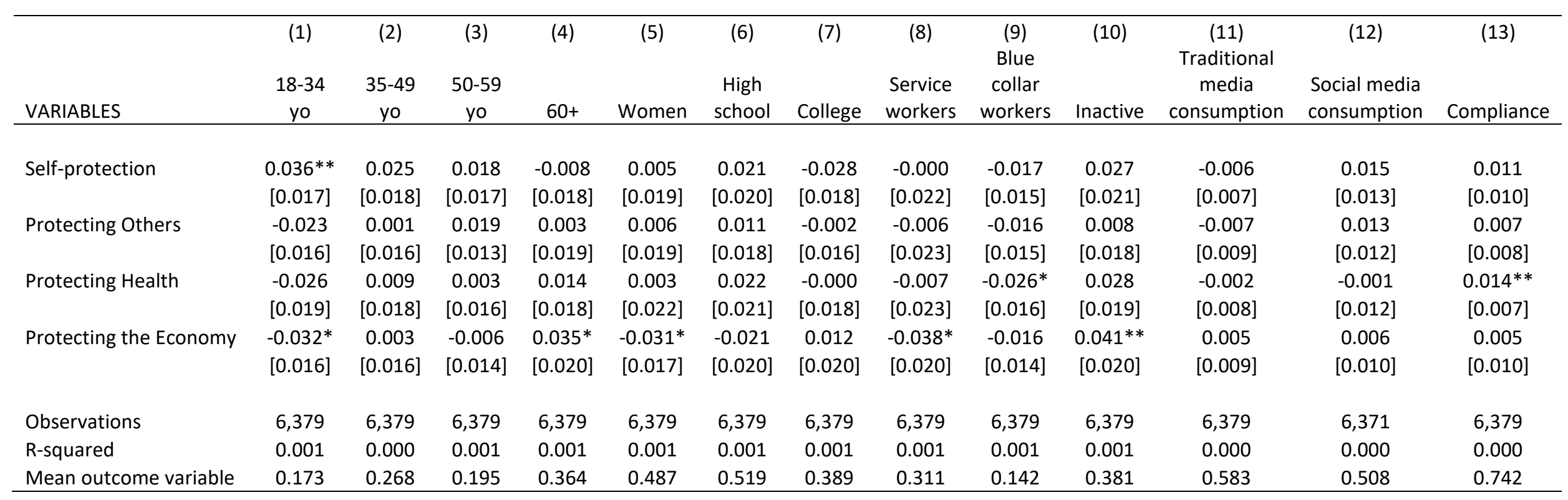


Table S8: Balance Tests (Panel B)

\begin{tabular}{|c|c|c|c|c|c|c|c|c|c|c|c|c|c|}
\hline VARIABLES & $\begin{array}{c}\text { Live } \\
\text { w/family }\end{array}$ & COVID & $\begin{array}{c}\text { Others } \\
\text { w/COVID }\end{array}$ & $\begin{array}{l}\text { Prob } \\
\text { COVID }\end{array}$ & $\begin{array}{c}\text { (18) } \\
\text { Prob } \\
\text { seriously } \\
\text { ill }\end{array}$ & Conservative & $\begin{array}{c}\text { Undeclared } \\
\text { ideology }\end{array}$ & $\begin{array}{l}\text { Trust in } \\
\text { scientists }\end{array}$ & $\begin{array}{c}\text { (22) } \\
\text { Risk } \\
\text { aversion }\end{array}$ & $\begin{array}{c}(23) \\
\text { Big } \\
\text { pharma's } \\
\text { fault }\end{array}$ & $\begin{array}{c}\text { (24) } \\
\text { China's } \\
\text { fault }\end{array}$ & $\begin{array}{c}(25) \\
\text { Vaccines' } \\
\text { side } \\
\text { effects }\end{array}$ & Attrition \\
\hline Self-protection & $\begin{array}{c}-0.025 \\
{[0.018]}\end{array}$ & $\begin{array}{c}-0.000 \\
{[0.008]}\end{array}$ & $\begin{array}{c}-0.022 \\
{[0.019]}\end{array}$ & $\begin{array}{c}0.011 \\
{[0.010]}\end{array}$ & $\begin{array}{c}-0.005 \\
{[0.010]}\end{array}$ & $\begin{array}{c}-0.018 \\
{[0.013]}\end{array}$ & $\begin{array}{c}0.008 \\
{[0.010]}\end{array}$ & $\begin{array}{c}0.022 \\
{[0.015]}\end{array}$ & $\begin{array}{c}0.005 \\
{[0.009]}\end{array}$ & $\begin{array}{c}-0.010 \\
{[0.016]}\end{array}$ & $\begin{array}{c}-0.011 \\
{[0.013]}\end{array}$ & $\begin{array}{c}-0.004 \\
{[0.013]}\end{array}$ & $\begin{array}{c}-0.014 \\
{[0.014]}\end{array}$ \\
\hline Protecting Others & $\begin{array}{c}-0.019 \\
{[0.018]}\end{array}$ & $\begin{array}{c}0.002 \\
{[0.007]}\end{array}$ & $\begin{array}{c}-0.006 \\
{[0.016]}\end{array}$ & $\begin{array}{c}0.017 \\
{[0.011]}\end{array}$ & $\begin{array}{c}0.006 \\
{[0.009]}\end{array}$ & $\begin{array}{c}-0.006 \\
{[0.014]}\end{array}$ & $\begin{array}{l}0.020 * \\
{[0.011]}\end{array}$ & $\begin{array}{c}0.034 * * \\
{[0.015]}\end{array}$ & $\begin{array}{c}0.002 \\
{[0.009]}\end{array}$ & $\begin{array}{c}0.005 \\
{[0.013]}\end{array}$ & $\begin{array}{c}0.004 \\
{[0.013]}\end{array}$ & $\begin{array}{c}-0.002 \\
{[0.010]}\end{array}$ & $\begin{array}{c}-0.018 \\
{[0.013]}\end{array}$ \\
\hline Protecting Health & $\begin{array}{c}0.009 \\
{[0.019]}\end{array}$ & $\begin{array}{c}-0.003 \\
{[0.007]}\end{array}$ & $\begin{array}{c}0.004 \\
{[0.017]}\end{array}$ & $\begin{array}{c}0.005 \\
{[0.012]}\end{array}$ & $\begin{array}{c}0.001 \\
{[0.011]}\end{array}$ & $\begin{array}{c}0.003 \\
{[0.015]}\end{array}$ & $\begin{array}{c}0.002 \\
{[0.011]}\end{array}$ & $\begin{array}{c}0.013 \\
{[0.018]}\end{array}$ & $\begin{array}{c}0.001 \\
{[0.011]}\end{array}$ & $\begin{array}{c}-0.008 \\
{[0.013]}\end{array}$ & $\begin{array}{c}0.011 \\
{[0.012]}\end{array}$ & $\begin{array}{c}-0.021^{*} \\
{[0.011]}\end{array}$ & $\begin{array}{c}0.002 \\
{[0.016]}\end{array}$ \\
\hline Protecting the Economy & $\begin{array}{c}-0.024 \\
{[0.019]}\end{array}$ & $\begin{array}{c}-0.005 \\
{[0.006]}\end{array}$ & $\begin{array}{c}-0.022 \\
{[0.017]}\end{array}$ & $\begin{array}{c}0.010 \\
{[0.010]}\end{array}$ & $\begin{array}{c}0.011 \\
{[0.010]}\end{array}$ & $\begin{array}{c}-0.007 \\
{[0.017]}\end{array}$ & $\begin{array}{c}0.001 \\
{[0.009]}\end{array}$ & $\begin{array}{c}0.017 \\
{[0.014]}\end{array}$ & $\begin{array}{c}-0.016 * \\
{[0.009]}\end{array}$ & $\begin{array}{c}-0.016 \\
{[0.013]}\end{array}$ & $\begin{array}{c}0.003 \\
{[0.012]}\end{array}$ & $\begin{array}{c}-0.007 \\
{[0.014]}\end{array}$ & $\begin{array}{c}-0.007 \\
{[0.013]}\end{array}$ \\
\hline Observations & 6,379 & 6,379 & 6,379 & 6,379 & 6,379 & 6,379 & 6,379 & 6,378 & 6,252 & 6,275 & 6,253 & 6,379 & 10,895 \\
\hline R-squared & 0.001 & 0.000 & 0.001 & 0.000 & 0.000 & 0.000 & 0.001 & 0.001 & 0.001 & 0.001 & 0.000 & 0.001 & 0.000 \\
\hline Mean outcome variable & 0.640 & 0.0409 & 0.238 & 0.520 & 0.549 & 0.242 & 0.0883 & 0.836 & 0.573 & 0.264 & 0.319 & 0.506 & 0.414 \\
\hline
\end{tabular}


Table S9: Effects of Experimental Treatments

(1) (2)

(3)

(4)

(5)

(6)

(7)

(8)

(9)

(10)

Among Individuals with Anti-vax Intentions

Anti-vax

Intentions Vaccination Vaccination Vaccination Vaccination Intentions Vaccination Vaccination Vaccination Vaccination

\begin{tabular}{|c|c|c|c|c|c|c|c|c|c|c|}
\hline VARIABLES & all & all & EU & UK \& US & AUS \& NZ & all & all & EU & UK \& US & AUS \& NZ \\
\hline \multirow[t]{2}{*}{ Self-protection } & 0.012 & -0.003 & 0.005 & -0.001 & -0.033 & -0.013 & $-0.063^{*}$ & -0.037 & -0.111 & $-0.178 * *$ \\
\hline & {$[0.013]$} & {$[0.018]$} & {$[0.025]$} & {$[0.020]$} & [0.043] & {$[0.014]$} & {$[0.035]$} & [0.041] & [0.098] & [0.063] \\
\hline \multirow[t]{2}{*}{ Protecting Others } & $0.022^{*}$ & $0.026^{*}$ & 0.022 & $0.043^{*}$ & 0.020 & $-0.030 * *$ & 0.000 & 0.009 & 0.017 & -0.070 \\
\hline & {$[0.012]$} & {$[0.015]$} & {$[0.020]$} & {$[0.021]$} & [0.041] & [0.014] & [0.040] & [0.049] & [0.077] & [0.089] \\
\hline \multirow[t]{2}{*}{ Protecting Health } & $0.030 * *$ & $0.038 * *$ & $0.047^{*}$ & 0.028 & 0.012 & $-0.033^{* *}$ & 0.029 & $0.083^{* *}$ & -0.097 & $-0.179 * *$ \\
\hline & {$[0.013]$} & [0.018] & [0.025] & {$[0.032]$} & [0.044] & [0.015] & [0.035] & [0.041] & {$[0.060]$} & [0.063] \\
\hline \multirow[t]{2}{*}{ Protecting the Economy } & $0.038 * * *$ & $0.029 *$ & 0.021 & $0.067 * * *$ & 0.014 & $-0.050 * * *$ & -0.003 & -0.014 & 0.102 & -0.013 \\
\hline & [0.012] & {$[0.016]$} & {$[0.021]$} & [0.017] & [0.049] & [0.013] & [0.045] & {$[0.055]$} & [0.134] & {$[0.056]$} \\
\hline Observations & 6,379 & 6,379 & 4,058 & 1,339 & 982 & 6,379 & 1,367 & 1,035 & 184 & 148 \\
\hline R-squared & 0.062 & 0.161 & 0.003 & 0.031 & 0.026 & 0.038 & 0.076 & 0.011 & 0.045 & 0.071 \\
\hline Country FE & Yes & Yes & Yes & Yes & Yes & Yes & Yes & Yes & Yes & Yes \\
\hline Mean outcome variable & 0.647 & 0.691 & 0.741 & 0.843 & 0.280 & 0.214 & 0.450 & 0.506 & 0.418 & 0.0946 \\
\hline Mean in the control group & 0.626 & 0.671 & 0.721 & 0.816 & 0.274 & 0.239 & 0.455 & 0.500 & 0.442 & 0.176 \\
\hline
\end{tabular}

